Kinsley Ekene Amaechi

University of Venda, Centre for Africa Studies

Raymond Raselekoane

University of Venda, Department of Youth and Gender Thohoyandou (South Africa)

\title{
COVID-19 LOCK-DOWN SOCIO-ECONOMIC CHALLENGES FACED BY HOUSEHOLDS IN RURAL AREAS: A PERSPECTIVE FROM VHEMBE DISTRICT, SOUTH AFRICA ${ }^{2}$
}

\begin{abstract}
National responses to the COVID-19 pandemic have varied from country to country. In South Africa, the response has included a compulsory 21-day lock-down entailing restrictions of social and economic activities among other things. This arguably helped the country to avoid further spread of the virus, especially in townships, informal settlements and rural communities, where access to health facilities is often difficult. However, it has also exposed rural households to unforeseen challenges. This paper explores these challenges in view of proffering policy measures to help such households during subsequent lock-down. University students living within such rural households were purposively sampled to solicit electronic data from heads of households in Vhembe district. Using a qualitative method to analyze the data gathered from 82 households, five major issues emerged which include access to basic needs such as groceries, whereas water and health items were some of the challenges. The situation in households is further compounded by 'limited source of income' due to retrenchments and shutdown of subsistence businesses. 'Depression and frustration' emanating from the fear of contracting the virus, spousal domestic abuse, inability to meet home obligations, family squabbles as well as boredom caused by movement restriction also constitute part of the challenges. The lack of needed information regarding the virus, and 'theft' were other two challenges. Based on these findings, the

\footnotetext{
${ }^{1}$ Ishmael.iwara@gmail.com

${ }^{2}$ Considerable thanks to T. Marima; T. Mathebula; D. A. Mauba; M. Ngoveni; K. Matshubeng; O. Nemutamba; A. Singo; S. N. Nkiyasi, and N. Rihangwele for volunteering to be part of the data collection process for the study.
} 
paper recommends thorough consideration of the identified challenges before the enforcement of such lock-down. It also encourages more improvement to be made in the area of service delivery in rural communities.

Keywords: Challenges, COVID-19, Households economy, Lock-down, Rural areas

\section{Introduction}

Since World War II, the world has never found itself in a state of pandemonium as in the one now. Nations are paralyzed as life has almost come to a standstill due to the lock-down imposed by governments in an attempt to curb the spread of the novel Coronavirus 2019 (COVID-19). As of the first week of April, an estimated 3.9 billion people, or more than half of the world's population, were under some form of lock-down in different countries of the world (Kaplan, 2020). This entailed restriction of social and economic activities and indefinite closure of boaders to curb the spread of COVID-19 pandemic. It also entailed increased effort in identification of infected individuals (through testing) and isolation of such persons.

South Africa was one of the first countries to impose a national lock-down. Amidst unprecedented surge in COVID-19 infections, on 23 $3^{\text {rd }}$ March South African President Cyril Ramaphosa announced a 21-day lock-down to mitigate the pandemic (iReport South Africa (iRSA), 2020). The lock-down started on $27^{\text {th }}$ March, 2020. This lock-down, among other things, entailed restrictions of social and economic activities throughout the country (except for those activities considered as essential); immediate ban of domestic and international travel; and indefinite closure of schools and institutions of higher learning throughout the country. Individuals were implored to self-isolate and stay at home, except for attending essential functions and procuring essential materials. People were also advised to avoid physical contacts with others and maintain proper hygienic measures such as wearing face masks in public domains, cleaning hands with soap and water or sanitizer when exposed to other people or objects (iRSA, 2020).

However, no matter how timely and useful these measures may have been, they have also posed some significant socio-economic challenges, especially for people living in the informal settlements and rural communities. This crop of people depends on daily economic activities for their livelihoods more than those in urban areas (Oni, Obi, Okorie, Thabede \& Jordan, 2002). As a result, they have been hit hard by the lock-down that disrupted almost all social and economic activities, which brought about a multiplicity of socio-economic challenges.

This paper explores these challenges with the aim of providing appropriate policy responses to mitigate the subsequent socio-economic challenges brought by the COVID19 lock-down. Using the case of Vhembe district, this paper investigates the challenges experienced by households in rural areas during the national lock-down from $27^{\text {th }}$ March until $16^{\text {th }}$ April 2020. The study also determines and ranks how much impact the identified challenges have on the rural households.

The paper is divided into sections that provide a historical overview of COVID-19, a brief literature review that discusses the socio-economic impact and challenges of similar health pandemics in history, the methodological approach, the research findings and discussion. The paper concludes with a highlight of the implications of the findings, as well as some comprehensive recommendations that are based on the findings. 


\section{Overview of Coronavirus and the South African lock-down}

Coronavirus 2019, also known as COVID-19, is an infectious disease caused by Coronavirus 2 (SARS-CoV-2) which often manifests itself in the form of an acute respiratory syndrome (WHO, 2020d). The major symptoms of this virus include fever, cough, tiredness, shortness of breath and loss of taste and smell (Bogoch et al., 2020; Chan et al., 2020; Wax \& Christian, 2020). In some cases, these mild symptoms have progressed to Acute Respiratory Distress Syndrome (ARDS) and further to cytokine storm, multi-organ failure, septic shock, and blood clotting (Bogoch et al., 2020; Chan et al., 2020; Wax \& Christian, 2020).

The virus mainly spreads through person to person contact either through droplets of saliva and/or discharge from the mouth and nose, when an infected person sneezes or coughs (World Health Organization (WHO) 2020a). COVID-19 is a respecter of no race, gender, boundary and socioeconomic class; the health science community is yet to come up with a vaccine for the disease (Rothe et al., 2020; Wax et al., 2020; WHO, 2020a). Hence, health workers dealing with COVID-19 patients have to manage the situation without a confirmed medication. This has arguably led to unprecedented amount of infections and fatalities from the virus.

According to WHO (2020d), the virus was first detected in Wuhan, a city in China, in November 2019. Since then, the virus has continued to spread to different countries around the globe, leading to severe socio-economic and health hazards. According to WHO (2020c) report from April 2020, almost all the regions of the world have confirmed fatalities and/or active cases of the virus. At this point, there are about 1,991,562 confirmed active cases, out of which 130,885 people have lost their lives. These deaths are mostly in South East Asia (21,790 cases/990 deaths), Europe (1,013,093 cases/89,317 deaths), and North America (707,121 cases/30,245 deaths). So far, Africa has had the lowest number of confirmed cases $(11,843)$ and deaths $(550)$.

Country statistics from April 2020 in the WHO (2020c) report also indicates that so far the virus has spread to 213 countries around the world. Of all these countries, the United State of America (USA) has recorded the highest number, with 604,070 infections, and 25,871 fatalities. This is followed by Italy and Spain, with 165,155 active cases /21,647 deaths and 177,633 cases/ 8,579 deaths respectively. Other countries with a significant number of infections include France (105,155 cases/17,146 deaths), the United Kingdom (98,480 cases/12,868 deaths), Iran (76,389 cases/4,777 deaths), Belgium (33,573 cases/4,440 deaths), China (83,797 cases/3,352 deaths), the Netherlands (28,153 cases/3,134 deaths), Brazil (25,262 cases/1,532 deaths), Turkey (69,392 cases/1,518 deaths), and Sweden (11,927 cases/1,203 deaths).

In Africa, South Africa has the highest number of cases $(2,506)$ and 34 deaths. Other countries with significant number include Algeria (2,160 cases/336 deaths), Burkina Faso (267 cases/22 deaths), the Democratic Republic of the Congo (855 cases/17 deaths), Cameroon (584 cases/14 deaths), Niger (144 cases/13 deaths) and Nigeria (373 cases/11 deaths). Many countries on the African continent have had no cases and fatalities by the time the research was performed in April 2020.

In an attempt to curb the spread of the virus, medical experts have recommended frequent hand washing, maintaining physical distance from others (especially from those with symptoms), quarantine (especially for those with symptoms), covering coughs, and 
avoiding contact with the face (WHO, 2020d). Virus carriers are expected to constantly use facemasks and avoid crowded environments whereas infected individuals should be isolated for at least 14 days (a period recommended to observe the development of COVID-19 in patients). Health experts have also recommended that countries shut down their economies for a few days to identify, checkmate and isolate individuals with the virus.

It was on this background that the South African government announced the 21-day lock-down on $23^{\text {rd }}$ March. The announcement followed what seemed to be a sudden spread of the virus, from 1 case (an inbound South African man that returned from Italy) on $5^{\text {th }}$ March, to 128 cases on the day the lock-down was announced. The lock-down, according to the South African President, was meant to protect and save the lives of people in the country (iRSA, 2020). To help oversee and lead the implementation of the nation's lockdown plan, the country also established the National Command Council for COVID-19 (South Africa Government, 2020). This entailed deployment of security personnel, especially in the most crowded townships and informal settlements to control the influx and unnecessary movement of individuals during the lock-down.

\section{Challenges faced by households in rural areas amidst the global pandemic}

Most often, rural populace, especially the low-income households, confront more severe consequences during economic lock-downs than those in the in urban areas (Andrulis et al., 2012; Groom et al., 2009; Massey et al. 2009; Parker et al., 2009). This is mostly because the clear majority of people in rural communities rely on basic supplies from the urban areas for sustenance. They also depend on daily subsistence activities for their livelihoods. When such economic and social activities are halted, it disrupts the urban-rural supply chain that trickles down to the rural households. This leaves them in an economic quagmire that goes deep within their communities (Massey et al. 2009).

Crisis-related studies have shown that at the peak of previous global emergencies similar to COVID-19, access to medical facilities, food supplies and proper education and/or needed information on the state of affair is always a challenge in rural areas (Massey et al., 2009; Andrulis et al., 2012; World Bank, 2020). This is largely because rural areas are often neglected by decision-makers. Amid crises, the government is saddled and pre-occupied with a huge responsibility of providing for the needs of people (Alexander, 2010; Allen, 2010; Chikulo, 2016; Brinkerhoff et al., 2018; Lam et al., 2018; Yusuf, 2018). Unfortunately, people in rural communities who seem to need government attention even more are given less attention. During the infamous Spanish-Flu pandemic (1919 to 1920), most communities in the US did not enjoy sufficient attention. Many households in the rural areas of the country were largely left on their own to struggle and contain the situation. As such, they suffered more severe socio-economic consequences far more than those in the urban areas (Dlomo, 2020). Even though there are no clear indicators that measure the effects, the historical United States Government Report reveals a more decline in economic activities in rural areas, lack of appropriate information, inaccessibility of health facilities, higher job losses, higher mortality rate globally in rural areas (Strath, 1919). The report also explained that the social and economic impact of the epidemic particularly among American Indians, who lived mostly in the rural areas, was "extremely severe" and significantly higher 
than that of those in the urban areas. The mortality rate was 4 times higher in rural areas than the rate reported for larger cities in the country.

This was also the same in the case of aboriginal indigenous people living within the rural communities in Australia. While ordinary Australians living in the urban areas had an average $0.4 \%$ mortality rate, the aboriginal communities within the rural areas in Australia, in contrast, had an over $50 \%$ mortality rate (Massey et al., 2009). The frequent and intense exposure to the virus, due to crowded housing conditions and limited access to medical care, contributed to the high attack rates, and the subsequent increased mortalities and decrease in economic activities in these communities (Strath, 1919; Massey et al., 2009).

Recent pandemics have also corroborated similar trends. For instance, the 2009 H1N109 swine flu had more significant devastating socio-economic impacts on communities in the rural areas than in the urban areas (Groom et al., 2009; Massey et al., 2009; Parker et al., 2009; Andrulis et al., 2012). A study of the number of mortalities in Australia during the pandemic indicates that indigenous people were over-represented in the Australian cases (Massey et al., 2009). The study shows that people within rural communities are approximately five times more likely than others in urban areas to be hospitalized for swine influenza (Massey et al., 2009). This proportion of people would also require intensive care treatment to stand a chance of surviving the pandemic. With the continued decline in both government presence and in socio-economic activities, the lack of information about the pandemic, and inaccessibility of the Australian social support and healthcare services, these communities become more vulnerable to severe socio-economic challenges and more intense health hazards that led to higher mortality rates than those in the urban areas (Massey et al., 2009).

The Human Immunodeficiency Virus (HIV) which hit Africa in the 1970s as well as the most recent Ebola outbreak in 2014, presented more devastating challenges in the rural areas than in the urban ones (Booysen et al., 2002; Oni et al., 2002; Parker et at., 2009; World Bank Report, 2013; Richards et al., 2015), even though the diseases were first diagnosed in urban areas. As earlier discussed, the rural households received a larger share of the consequences. Facilities for the diagnoses and treatment of such diseases are mostly not found in the rural areas in the way they are found in the urban areas (Oni et al., 2002). This makes it cost and time effective for people in the urban areas. In most cases, people living in the rural areas travel long distances to access health facilities. These challenges suggest the need to scale up infrastructural development, both in health and education systems in rural areas; a concern that should be addressed with urgency.

Empirically, South Africa is not immune to these challenges either (Booysen et al., 2002; Oni et al., 2002; Parker et. al., 2009; Alexander, 2010; Chikulo, 2016; Brinkerhoff et al., 2018), as the research in previous health pandemics shows how rural households have grappled with devastating challenges. This study was conducted to explore the challenges faced by households in rural areas during the COVID-19 lock-down. This study helps to provide a clue about what people in rural areas have been going through during the lock-down. The findings of the current study which draw on Vhembe district municipality can be used to develop and shape policy actions taken by government in response to the outbreak of the COVID-19. The study forces the government not to take interests of people in rural areas during pandemics as an afterthought. It calls on government to consider appropriate measures that can ensure rural household sustainability during similar global crises in the future. 


\section{Research Method}

The study adopted a case study research design which allows for collection and analysis of qualitative data (Creswell, 2017). It is most ideal given that it provided room to interact and explore the participants' experiences of the lock-down for the COVID-19. Due to movement restriction and social distancing regulations, physical contact with the participants was impossible. Thus, electronic data collection techniques such as telephone, Skype and WhatsApp were utilized for conducting in-depth one-to-one interviews with the participants. However, before the data collection, a purposive sampling technique was used to identify nine University of Venda students as key informants. The rationale was based on the fact that these students were from the households in rural areas in Vhembe District in Limpopo province. They had contact with other similar households living in rural areas. They also spoke indigenous languages like Venda and Tsonga, and were also familiar with the use of the electronic data collection technique.

The study relied on semi-structured in-depth interviews of heads of households from 12 villages in Vhembe district (see Table 1). Using a convenient sampling technique, the students were able to engage with 82 participants on the challenges they face during the lock-down. While $57 \%$ of the participants were females, $43 \%$ were males. The in-depth interviews were guided by data saturation.

Only those participants who conceded to the ethical consent of the study were interviewed accordingly. The narratives consolidated from the 82 participants were captured in a Microsoft word document and fitted in to Atlas.ti v8 software for the qualitative analysis. The open coding system within the software was harnessed for the analysis. This was useful for categorizing the participants' narratives in themes.

\section{Study Area}

The study area is located in Vhembe district, Limpopo province, which is in the northern part of South Africa. It shares boundary with Botswana, Mozambique and Zimbabwe. The district is composed of four local municipalities, namely: Collins Chabane, Thulamela, Makhado and Musina. The choice of the 12 villages selected for this study was based on rurality and distance to service centres. Just like any other district in the province, Vhembe is known for mainly being rural and for its large scale and subsistent agrarian activities. This, alongside various forms of business, constitutes a larger part of sustainable livelihood.

The district has a population of over 1.1 million inhabitants and covers an area of $21,407 \mathrm{~km}^{2}$ (Statistics South Africa, 2011). The area is predominantly rural and deficient with critical basic services (Chauke et al., 2013). It has been profiled to produce up to $4.4 \%$ of the country's total agricultural output, $8.4 \%$ of the sub-tropical fruit and $6.3 \%$ of its citrus (Vhembe District Municipality, 2018). Limpopo Province is one of those with the highest poverty level and unemployment in the country, with Vhembe district contributing significantly. Majority of the households are involved in roadside vending, micro-scale enterprises and other forms of menial jobs to sustain a living. 


\section{Results}

As depicted in Figure 1, five major themes and several items emerged. Firstly, getting basic needs such as groceries, water and health items. The source of income for a living resulting from retrenchments and shut-down of small businesses posed another challenge. Depression and frustration caused by the fear of contracting the virus, spousal abuse, inability to meet home obligations, boredom due to movement restriction as well as household squabbles were mentioned. 'Access to needed information' regarding the virus resulting in anxiety, and 'theft' were also identified.

\section{Getting basic needs}

Amid the lock-down, access to health facilities was a challenge to some rural residences. Even though the government had categorized all forms of health systems such as hospitals, clinics and local pharmacies as essential, which allowed them to be operational throughout the lock-down, most of them, especially the privately-owned ones, were inefficient and sceptical in attending to people's needs in rural areas. It was mainly because of the fear of the virus. This became a serious challenge for people in the rural households, as they had to travel many miles to access health facilities:

"...I could not take my wife to the hospital; I don't have the means to get private transport from the village to town. Even when we tried to reach out to the hospital to assist with an ambulance, no response..." (P2)

Undeniably, the government had put in place the measures that ease movement for essential services such as health. Yet these measures in most cases where thwarted by the security personnel's approach in enforcing the law.

“...security personnel don't wait for an explanation; they beat and even detain anyone caught out there without a permit..." (P7).

Many also expressed frustration caused by the strenuous process of securing a permit to move from one community to another from police authorities, political representatives or tradition leaders. Transport scarcity resulted in long queues at the park, which left some people behind. Hospitals were overcrowded as they were servicing many villages, and this resulted in the easy spread of the virus.

"We fear that if we take our father to the hospital, he might contract the virus and die. Health workers in our area are very ignorant. Most hospitals are often crowded; health workers are not even practising strict precautions amid the pandemic..." (P27).

During the 21-day lock-down, most small businesses in the villages were shut down. There were few supermarkets operating in remote and rural areas. People in remote areas were forced to travel for long distances to buy items in large scale to serve them for weeks. Public transport operation was restricted to certain hours limiting movement to 6 am - 10 am and $4 \mathrm{pm}-10 \mathrm{pm}$. Apart from the challenge of queuing for transportation, the queues at the shopping malls posed a serious challenge. High demand for protective materials such as sanitizers and masks as well as food items inflated prices, leaving the poor with no option than letting go of some basic items. Some of the items were out of stock as indicated below. 
“...rural shops were not receiving sufficient supplies; it causes inflation, making it difficult for us to buy much needed basic items with our limited resources...” (P12).

"The government should have subsidised basic commodities, put price control task force to prevent the inflation of basic items. People do what they wish with their markets. They take advantage of the situation to exploit us..." (P48).

"We only heard supplies of personal protective materials to people, apparently the vulnerable have been marginalised...; we did not see anything." "Even water the government promised to bring has been a challenge, we have to wait in long queues for hours every day to get water..." "...the government wants us to wash hands with water even though we do not have enough to drink." (P34).

"Politicians used those items for a campaign, building of social ties and enriching themselves. They share both the protective materials and food items to their political members, friends and families." (P1).

\section{Source of income}

Just like in the urban areas, all forms of economic activities were forced to close down in rural areas as well. Only businesses for essential services were allowed to operate during the lock-down. Small business operators, especially vendors stopped operating in line with the lock-down regulations. Unfortunately for some, they had been retrenched before the end of 21-day lock-down. Thus, savings, social grant and donated food parcels were means of survival. It becomes a huge challenge to those who only relied on donated food parcels for survival:

"The government should never have closed livelihoods paths for rural people without ensuring proper alternative support measures. Populated structures such as schools, churches, cinemas, gyms, museums, sports could be restricted not small businesses that provide basic needs for our us..." (P11)

"Every business is essential to the owner, so I don't understand what the government meant by 'essential', refusing us to do our businesses. Hunger will end up killing even more than the virus..." (P21)

"Small businesses that provide food on the table of rural poor were locked down while big/rich owned businesses such as 'Shoprite', 'Spar', 'Game', 'Boxer' and Pick $n$ Pay were authorised to operate. The government adds more wealth to the rich at the detriment of the poor. They could have provided protective materials and proper orientation to small business holders to help them operate and earn a living..." (P63)

\section{Dealing with depression and frustrations}

The lock-down restricted movement, limiting people to their houses. Boredom becomes a major issue to people who stay alone while many others find it difficult to deal with oppressions from people around them.

"A day has not passed by since the 21-day lock-down without a fight with my wife. It is more fearful at home than the virus out there. If not for the lock-down, I would be in my workplace or hook up with friends to overcome her; sincerely I am stuck..." (P7). 
"It is either sex or food... My husband hits me hard every day. He caged me so badly and does anything he feels at will. Usually, our neighbours come to my rescue but they stopped for the fear of the virus. Unfortunately, I don't have anyone to report, I could not travel to my parents due to the lock-down..." (P24).

The fear of losing means of income, living with hunger and possibly seeing the world ending because of the pandemic grasp the minds of many households. Similarly, there is anxiety about spousal abuse as well as the pressure to meet family household obligations such as food and utility bills. This challenge forcefully changed the composition of household consumption as many would have to economise limited resources such as food, water and electricity to survive the lock-down. Some participants had issues with house rent. To many, space was an issue. The home becomes congested as everyone returned home because of COVID-19. Some had their spouses and children with them:

"... I felt hopeless, seeing how we struggle to get basic needs during 21 days..." "It was scary". "No means of livelihood, no savings; we are grateful to the government for the child's social grant. Things would be out of hands..., people are suffering..." (P31).

\section{Access to needed information}

Rural households believed the scale of awareness regarding the pandemic was not sufficient in their areas. Most families in rural areas struggle to access first-hand news from the government and understand what the virus is all about except for those that can afford television and radio sets. As a result, many rely on neighbours or friends for basic information. Regardless of the source, anything that teaches them about the cause of the pandemic, precaution and cure of the virus is appreciated. Some of the households said:

"... We struggle to know what COVID-19 is all about. No one could explain better to us in this village. All we saw was security personnel who walk around forcing people to stay inside their houses..." (P16).

"Some time ago, we made concoctions with lemon and ginger. Our neighbour told us it is effective in curing the virus. It has been our morning and night tea, not until we called our daughter in the city who advised us to stay indoors, the virus is dangerous and does not have a cure yet. We panicked..." "...Maybe proper community engagement and sensitization about the pandemic would reduce false information and take off anxiety the vulnerable are facing..." (P19).

There is a widely shared belief amongst the participants that people living in remote and rural areas in South Africa continue to be denied their human rights such as access to information regarding education, access to resources such as internet and electricity which are basic to education, and access to education itself. Even though education is free, the lack of basic infrastructure in some areas constrains many of the privilege:

"...It is not very clear the modalities government has put in place to enhance e-learning, no one has talked to us about that yet pupils are expected to be engaging online for their classes. Unfortunately, my children will be left behind education; apart from a computer, which we don't have to download lesson materials, access to the internet in this village is a big issue..." (P71). 


\section{Theft}

While everyone is expected to be indoors except for essential workers, criminality abounds amid COVID-19. Closed schools and shops were vandalised and looted. Some households also experienced burglaries which compounded their COVID-19 trauma.

"Area boys go around during this period stealing from people in this village. They vandalise people's properties. This is because the level of desperation this time has increased."

Evidently, households that have experienced these kinds of incidences had to deal with loss of scarce resources that they desperately needed during the lock-down. In most cases, the participants had blamed the government for enforcing lock-down without proper security measures.

\section{Discussion of the Findings}

This study has identified numerous challenges that rural households in Vhembe district grapple with during the South African lock-down due to COVID-19. The challenges were categorized into five themes. They include getting basic needs such as groceries, water and health items; limited source of income due to retrenchments and shut down of subsistent businesses; depression and frustration caused by fear of contracting the virus, domestic violence, inability to fulfill home obligations and family squabbles, as well as boredom caused by movement restriction; inability to access needed information regarding the virus; and theft.

Evidently, these challenges are not far removed from the previous research regarding rural households globally and within the context of South Africa. This suggests that the current study has only contributed to crystallizing and defining the challenges. The argument is consistent with Massey et al. (2009), Parker et al. (2009) and World Bank Report (2020), within which access to basic services was found to be a very serious challenge to people living in rural areas, especially during global health crises. As with the previous studies (Massey et al., 2009, Parker et al., 2009, and World Bank, 2020), these challenges (access to health facilities, basic welfare and lack to information) underline recurring issues that people living in rural areas in the different parts of the world are confronted with in their daily lives. These realities only become more accentuated at the dawn of lock-down of social and economic activities following the outbreak of COVID-19. Their severity is also exacerbated because people living in such communities totally depend for their subsistence on the social and economic activities which were obstructed by imposition of the lock-down to contain the spread of COVID-19.

Another significant aspect of the current study's findings is the confirmation that rural households in Vhembe had suffered and had been deprived access to basic services from the government (Emenike et al., 2017; Drummond \& Snowball, 2019; Fransman \& $\mathrm{Yu}, 2019$ ). The findings in the current study, much like in the above mentioned studies show that access to basic roads, water supply, electricity and the internet remain a challenge for rural households. In this situation, people such as students who live in the rural areas suffer most since the availability of these resources is critical for their academic engagements. Unlike people in other parts of the country, they are left behind in the e-learning programme encouraged by the government. In general, these suggest that there is a huge 
disparity in the provision of basic services for rural and urban communities. Governments tend to prioritize people living in the major cities at the detriment of those in the rural communities. Urban areas attract a large proportion of government investments on infrastructure, while little attention is paid to the rural communities where such services are muchneeded (Vearey et al., 2010; Saleem \& Abideen, 2011; van der Hoeven et al., 2012; Brain et al., 2014; Walker\& Mathebula, 2019). Even though rural areas contribute significantly to raw materials, food and manpower required to sustain urban economies (van der Hoeven et al., 2012), they remain marginalized when it comes to distribution of basic services. The COVID-19 outbreak has shown the need to scale up provision of these basic services, especially internet connection services and access to other essential services in rural areas.

Earlier, a discourse in Emerging Voices Report (2005) captures marginalization of rural households and expresses a nagging feeling that unless the real gap between urban and rural areas is delineated, accepted and given adequate attention, inequalities will persist and come to haunt generations to come. Over two decades after the demise of apartheid, rural areas in the country are still grappling with insurmountable obstacles, with little or no change in sight for those who need it most (Moletsane, 2012; Mburu \& George, 2017; Drummond \& Snowball, 2019). This calls for swift intervention measures to address rural-urban inequality, poverty, unemployment, affordability and access to health care. The effectiveness of what has been done so far in South Africa to address rural-urban inequality is still questionable given that very little has changed after 25 years of South Africa's democracy. Scholars such as Turpie et al. (2008), De Kadt and Lieberman (2017), Ndebele and Lavhelani (2017), and Nkomo (2017) revealed that the masses often attribute such failure to a high level of corruption, incompetence and ethnic divide.

Empirically, majority of rural households survive through subsistence farming, micro-businesses, and mini-jobs (Hunter et al., 2014; Ubisi et al., 2017; Wilkinson, 2017). They hardly have savings from their earnings for difficult times. They depend on day to day economic and social activities of the country to survive. This being the case, a total shutdown of their economic and social activities means a total shutdown of their source of livelihood and hence starvation. Even though the government has put social relief measures, such as R500 increase in the social grant and a R350 welfare grant for formally unemployed people in the country (South Africa Government, 2020), the participants' narrative indicates that these do very little to enable people within the rural households to meet their basic needs. In some cases, the study also shows that the people in rural areas have often found it impossible to access government assistance meant for them. This, coupled with starvation has caused more panic than the virus itself.

The issue of theft or burglary in South Africa as discussed amidst crises is well-documented in the literature (Misago, 2019; Ngcamu \& Mantzaris, 2019; Marumo et al., 2019). People in developing countries have often demonstrated strong tendencies of breaking into public and private properties to loot during crisis, especially in the urban areas. In 2018 for instance, businesses were raided amidst the xenophobic crisis in some areas of Kwazulu-Natal and Gauteng with much focus on establishments belonging to black African migrants (Mngadi \& Njoli, 2018; Ogunnoiki \& Adeyemi, 2019). A similar incident occurred in 2019, resulting even in loss of lives (Times Live, 2019; Maromo, 2019). At the peak of COVID-19 in 2020, many South Africans took to streets, broke and looted shops (Times Live, 2020; SABC News, 2020). Therefore, theft, especially in the urban areas, during a physical crisis 
in the country, is nothing new. However, when it comes to the rural communities there seems to be little or no existing literature on this. This could mean that there are relatively low cases of such issues as oppose the urban areas or lack of documentation. It is not clear either what measures the government has in place to curb such incidences.

Just like theft, domestic abuse, especially gender-based violence, has also been a burning issue in the country (Sexual Violence Research Initiative, 2020). Arguably, all genders perpetrate and experience domestic partner abuse. However, population-based surveys show an alarming surge of abuse cases against women, with intimate partner violence being the most common (Dunkle et al., 2004; Machisa et al., 2011; Sexual Violence Research Initiative, 2020). For instance, over $56 \%$ of South African women murdered in 2009 were victims of intimate male partner violence (Jewkes et al., 2009). Up to $40 \%$ of the total number of women in the country have gone through sexual and/or physical intimate partner abuse (Jewkes et al., 2011; Jewkes, 2012), and over 50\% have experienced either emotional or economic abuse from their partners (Jewkes, 2012; Sexual Violence Research Initiative, 2020). To mitigate the surge, a protection order was enforced, civil society organizations and Non-Governmental Organizations (NGOs) joined forces in the formation of the National Strategic Plan, as well as programmes that front campaigns against gender-based domestic violence.

Among a myriad of others, FAMSA, Legal Aid South Africa, People Opposing Women Abuse (POWA) are functional bodies established in an effort to curb the scourge of gender-based violence. A cursory look at these structures shows that their scope of operation has not covered rural areas sufficiently as many rural households still lack basic orientation on steps to follow when abused (Usdin et al., 2005; Dunkle et al., 2007; Lince-Deroche et al., 2018; Shai, 2018). It becomes even difficult for them as they do not understand their rights, what private or government agency to reach out or how to coordinate their actions to escape such scenarios when they live in situations where there is a huge lack of government presence. This could lead to a great feeling of insecurity and vulnerability that is internalized and carried over to other areas of their lives.

The lack of proper representation also explains the reasons rural households struggle with access to basic information (education) regarding the pandemic. This often results in anxiety and depression. Amid crises, rural households rely mostly on their representative to spur their hopes. Participants' narrative shows that little or no efforts were made by the government to take this into consideration. Basic information, as part of any consideration, remained accessible to the few who could afford the media stations. Apparently, except for those with access to television sets, radio and smartphones, others remain unaware of what is going on with other communities in the country. This supports Balfour and De Lange (2012) who maintain that even though education is pivotal for developing environmental awareness, solving societal challenges and critical for transformation, it remains an underexplored dimension of rural life. Arguably, fear from further spread of the virus may have constrained political representatives and traditional leaders to take measures. Distribution of food parcels amidst the lock-down was successful even in the rural areas (Asma, 2020; Mbuza, 2020; Pule, 2020); a piece of information may as well go around using a similar technique. It is important to bring rural households to the social plane of events amidst the crises. 


\section{Conclusion}

A pandemic response driven only by medical or economic data alone is obviously inadequate. The response to health hazards such as these needs to be shaped by the specificity of needs in different demographics of the country. Continuous expansion of resources for monitoring and tracking is critical, as is successful management of broad and rapidly evolving data flows on the spread of the pandemic. But understanding the socio-economic problems faced by people living in rural areas, where relief is most needed, and the most effective kind of relief is just as important. This kind of understanding can only be provided by reliable social data, and the governance infrastructure to absorb and respond to crises that may crop up either in rural or urban areas. This exploratory study reveals that 'getting basic needs' such as groceries, water and health items were some of the challenges grappled with by households in rural areas. 'Source of income' for a living resulting from retrenchments and shut-down of small businesses posed another challenge. 'Depression and frustration' caused by the fear of contracting the virus, spousal abuse, inability to meet home obligations, boredom due to movement restriction as well as household squabbles were also mentioned. 'Access to needed information' regarding the virus resulting in anxiety, and 'theft' constituted part of the challenges.

\section{Recommendations}

COVID-19 outbreak ignites the need for the government to scale up infrastructural development in rural areas. Basic amenities such as internet coverage, water supply, electricity and tarred roads are essentials that should be made available in rural areas as well. It is expected that such development will spike the establishment of service centres nearby, thereby enhancing easy access to basic services. Information is crucial. The government and traditional leaders should scale up involvement of rural households in decision making that affects them. Corruption amongst political representatives in the country is still a burning issue which needs to be addressed to ensure that the basic services are also available in rural areas. It is worth emphasizing that absence of quantitative measures has left a great deal of findings generalized. Thus, future studies should harness measures to test the identified challenges in a wider array for quality assurance. 
Ишмаел Обаеко Ивара ${ }^{1}$

Универзитет у Венди,

Институт за рурални развој

Фаит Мусвипва

Универзитет у Венди,

Департман за социологију

Кинсли Екене Амаечи

Универзитет у Венди,

Центар за афричке студије

Рејмонд Раселекоане

Универзитет у Венди,

Департман за омладину и родна питања

Тохојанду (Јужноафричка Република)

\section{COVID-19 И ДРУШТВЕНО-ЕКОНОМСКИ ИЗАЗОВИ СА КОЈИМА СУ СУОЧЕНА ДОМАЋИНСТВА У РУРАЛНИМ ПОДРУЧЈИМА ТОКОМ ИЗОЛОВАНОСТИ: ИЗ ПЕРСПЕКТИВЕ ОКРУГА ВЕМБЕ У ЈУЖНОЈ АФРИЦИ}

(Превоg In Extenso)

Сажетак: Национални одговори на пандемију COVID-19 разликују се од државе до државе. У Јужној Африци, овај одговор обухватио је законом уведено ванредно стање у трајању од 21 дан које, између осталог, захтева ограничења друштвених и економских активности. Ово је највероватније помогло земљи да спречи даље ширење вируса, поготово у градовима, неформалним насељима и руралним заједницама, где је често тешко доћи до здравствених установа. Међутим, изолација је такође изложила домаћинства непредвиђеним изазовима. Овај рад истражује те изазове с циљем да пружи мере политике које ће домаћинствима помоћи током изолације. Студенти који живе у руралним домаћинствима смишљено су узети као узорак како би се добили електронски подаци од глава домаћинстава у округу Вембе. Примењујући квалитативни метод у анализи података сакупљених из 82 домаћинства, утврђено је пет главних проблема који се односе на доступност основних потреба попут намирница, при чему су међу тим изазовима била питања воде и здравствених услуга. Ситуација у домаћинствима је додатно погоршана „ограниченим извором прихода” услед смањивања трошкова и затварања малих предузећа. „Депресија и фрустрираност” проистекле из страха од заразе вирусом, супружничко злостављање, немогућност

\footnotetext{
${ }^{1}$ Ishmael.iwara@gmail.com

2 Велику захвалност дугујемо Т. Марима; Т. Матебула; Д. А. Мауба; М. Нговени; К. Матсхубенг; О. Немутамба; А. Синго; С. Н. Нкијаси и Н. Рихангвеле који су добровољно учествовали у процесу сакупљања података за ову студију.
} 
испуњавања кућних обавеза, породичне свађе, као и досада изазвана ограниченим кретањем такође чине саставни део ових изазова. Недостатак неопходних информација о вирусу и „крађа” су следећа два изазова. На основу ових налаза, рад препоручује темељно разматрање препознатих изазова пре увођења изолације. Такође се предлаже додатно побољшање у области обезбеђивања услуга у руралним заједницама.

Кључне речи: изазови, COVID-19, економија домаћинства, изолација, рурална подручја

\section{Увод}

Још од Другог светског рата свет се никада није нашао у хаотичном стању које тренутно влада. Државе су паралисане јер је живот готово стао због изолације коју владе уводе у покушају да зауставе ширење новог коронавируса 2019 (COVID-19). Од прве седмице априла, отприлике 3,9 милијарди људи, односно више од половине светског становништва у разним земљама света, нашло се у неком виду изолације (Kaplan, 2020). То је наметнуло ограничавање друштвених и економских активности и затварање граница до даљег како би се зауставило ширење пандемије COVID-19. То такође изискује повећане напоре у откривању заражених појединаца (путем тестирања) и њихову изолацију.

Јужна Африка била је једна од првих држава које су увеле ванредно стање на националном нивоу. Због незабележеног пораста заразе вирусом COVID-19, јужноафрички председник Сирил Рамафоса објавио је ванредно стање у трајању од 21 дан како би се ублажила пандемија (iReport South Africa (iRSA), 2020). Ванредно стање почело је 27. марта 2020. године. Између осталог, ово подразумева ограничавање друштвених и економских активности широм земље (осим активности које се сматрају неопходнима); забрану путовања у оквиру земље и у иностранство, и затварање до даљег школа и високошколских установа у читавој земљи. Појединци су замољени да поштују самоизолацију и остану код куће осим када морају да обаве основне функције и набаве основне ствари. Људима је такође саветовано да избегавају физички контакт са осталима и да примењују прописне хигијенске мере као што је ношење маске у јавном простору, прање руку сапуном и водом или чишћење дезинфекционим средством приликом контакта са другим људима или предметима (iRSA, 2020).

Међутим, без обзира на то колико су ове мере биле правовремене и корисне, оне су такође донеле и значајне друштвено-економске изазове, нарочито за људе који живе у неформалним насељима и руралним заједницама. Опстанак ове групе људи зависи од свакодневних економских активности више него што је то случај са људима у градским подручјима (Oni, Obi, Okorie, Thabede \& Jordan, 2002). Због тога су они били тешко погођени ванредним мерама које су обуставиле готово све друштвене и економске активности, што је довело до низа друштвено-економских изазова.

Овај рад истражује те изазове у циљу давања одговарајућих одговора како би се ублажили наредни друштвено-економски изазови изазвани затварањем због пандемије COVID-19. На примеру округа Вембе, овај рад истражује изазове које су доживела домаћинства у руралним подручјима током затварања државе од 27. марта до 16. априла 2020. године. Студија такође одређује и рангира утицај који утврђени изазови имају на сеоска домаћинства. 
Рад је подељен у одељке који дају хронолошки преглед пандемије COVID-19, кратак осврт на литературу која говори о друштвено-економском утицају и изазовима сличних пандемија током историје, методолошки приступ, налазе истраживања и дискусију. На крају рада истакнуте су импликације налаза, као и свеобухватне препоруке засноване на тим налазима.

\section{Преглед коронавируса и изолације у Јужној Африци}

Коронавирус 2019, познат и као COVID-19, је заразна болест коју изазива коронавирус 2 (SARS-CoV-2), а која се често јавља у виду акутног респираторног синдрома (WHO, 2020d). Главни симптоми овог вируса су повишена температура, кашаљ, умор, кратак дах и губитак чула укуса и мириса (Bogoch et al., 2020; Chan et al., 2020; Wax \& Christian, 2020). У појединим случајевима ови благи симптоми прелазе у акутни респираторни дистрес синдром (ARDS), а затим и у синдром „цитокинске олује”, отказивање функције више органа, септички шок и згрушавање крви (Bogoch et al., 2020; Chan et al., 2020; Wax \& Christian, 2020).

Вирус се углавном преноси контактом са човека на човека, било путем капљица пљувачке односно излучевина из уста и носа када заражена особа кине или се закашље (Светска здравствена организација WHO, 2020a). COVID-19 не прави разлику између расе, пола, граница и друштвено-економских класа; научници у области здравства тек треба да произведу вакцину за ову болест (Rothe et al., 2020; Wax et al., 2020; WHO, 2020a). Стога здравствени радници који раде са пацијентима зараженим вирусом COVID-19 морају да управљају ситуацијом без потврђених лекова. Ово је највероватније довело до незапамћеног броја заражених и преминулих особа.

Према Светској здравственој организацији (WHO 2020d), вирус је прво откривен у кинеском граду Вухан у новембру 2019. године. Од тада се вирус проширио у разне земље широм планете, изазивајући озбиљне друштвено-економске и здравствене последице. Према извештају из априла 2020 (WHO, 2020c), готово сва подручја света потврдила су смртне случајеве односно случајеве особа заражених вирусом. У овом тренутку има око 1.991.562 потврђених активних случајева, од којих је 130.885 особа изгубило живот. Смртни случајеви забележени су, пре свега, у Југоисточној Азији (21.790 заражених/990 преминулих), Европи (1.013.093 заражених/89.317 преминулих) и Северној Америци (707.121 заражених/30.245 преминулих). До сада Африка има најмањи број потврђених (11.843) и смртних случајева (550).

Државна статистика из априла 2020. у извештају WHO (2020c) такође указује на то да се вирус проширио у 213 земље широм света. Међу тим земљама, Сједињене Америчке Државе (САД) забележиле су највећи број, са 604.070 заражених и 25.871 смртних случајева. Затим следе Италија и Шпанија са 165.155 активних случајева/21.647 преминулих, односно 177.633 активни случајева/8.579 преминулих. Остале земље са значајним бројем заражених су Француска (105.155 заражених/17.146 преминулих), Велика Британија (98.480 заражених/12.868 преминулих), Иран (76.389 заражених /4.777 преминулих), Белгија (33.573 заражених/4.440 преминулих), Кина (83.797 заражених/3.352 преминулих), Холандија (28.153 заражених/3.134 преминулих), Бразил (25.262 заражених/1.532 преминулих), Турска (69.392 заражених/1.518 преминулих) и Шведска (11.927 заражених/1.203 преминулих). 
На афричком континенту, Јужна Африка има највећи број заражених (2.506) и 34 преминулих особа. Остале земље са значајним бројем су Алжир (2.160 заражених/336 преминулих), Буркина Фасо (267 заражених/22 преминулих), Демократска Република Конго (855 заражених/17 преминулих), Камерун (584 заражених/14 преминулих), Нигер (144 заражених/13 преминулих) и Нигерија (373 заражених/11 преминулих). Исто тако, бројне земље на афричком континенту нису забележиле ниједан случај заражених или преминулих особа до априла 2020. када је ово истраживање спроведено.

У покушају да се заустави ширење вируса, медицински стручњаци препоручују често прање руку, одржавање физичке дистанце међу људима (нарочито са онима који имају симптоме), карантин (нарочито за оне са симптомима), стављање руке преко уста када се кашље и избегавање додиривања лица (WHO, 2020d). Од преносилаца вируса очекује се да носе маске и избегавају окружења са много људи, при чему заражени појединци треба да се изолују најмање 14 дана (препоручени период за посматрање развоја вируса COVID-19 код пацијената). Здравствени стручњаци такође препоручују да земље затворе привреду на неколико дана како би се открили, ставили под контролу и изоловали појединци заражени вирусом.

У оваквом контексту, јужноафричка влада је 23. марта прогласила ванредно стање у трајању од 21 дан. Проглашење је уследило након очигледно наглог пораста заразе са 1 заражене особе (Јужноафриканац који се вратио из Италије) 5. марта на 128 случајева на дан проглашења ванредног стања. Према председнику Јужне Африке, затварање је имало за циљ да заштити и спасе животе људи у земљи (iRSA, 2020). Како би се надгледало и остварило спровођење националног плана о затварању, земља је такође основала Национално командно веће за COVID-19 (South Africa Government, 2020). Ово је подразумевало распоређивање радника обезбеђења, нарочито по најгушће насељеним градовима и неформалним насељима, како би се контролисао прилив и непотребно кретање појединаца током ванредног стања.

\section{Изазови са којима су се суочила домаћинства у руралним подручјима током глобалне пандемије}

Сеоско становништво, нарочито домаћинства са ниским приходима, током затварања привреде се чешће суочава са најозбиљнијим последицама него она у градским подручјима (Andrulis et al., 2012; Groom et al., 2009; Massey et al., 2009; Parker et al., 2009). Ово је углавном због тога што огромна већина људи у руралним заједницама зависи од основних потрепштина које добија из градских подручја. Њихово преживљавање зависи и од свакодневних пољопривредних активности. Када се поменуте економске и друштвене активности обуставе, то доводи до прекида у ланцу снабдевања између града и села који води до сеоских домаћинстава. Услед тога они падају у све дубљи понор у оквиру њихових заједница (Massey et al., 2009).

Студије везано за кризу показују да је, на врхунцу претходних глобалних ванредних ситуација сличних пандемији COVID-19, изазов у сеоским подручјима увек представљао приступ здравственим установама, залихама хране и правилном образовању, односно неопходним информацијама о стању ствари (Massey et al., 2009; Andrulis et al., 2012; World Bank, 2020). Разлог је првенствено то што доносиоци одлука често запостављају сеоска подручја. током кризе, влада је оптерећена и 
заокупљена огромном одговорношћу да испуни потребе свог народа (Alexander, 2010; Allen, 2010; Chikulo, 2016; Brinkerhoff et al., 2018; Lam et al., 2018; Yusuf, 2018). Нажалост, људи у руралним заједницама којима влада очигледно треба да поклони више пажње заправо добијају мање пажње. Током злогласне пандемије шпанског грипа (од 1919. до 1920), већина заједница у САД била је прилично запостављена. Бројна домаћинства у сеоским подручјима те земље препуштена су сама себи у борби и контроли ситуације. Самим тим, ова домаћинства претрпела су далеко озбиљније друштвено-економске последице од оних у градским подручјима (Dlomo, 2020). Иако не постоје јасни показатељи који мере ефекте, Извештај америчке владе из тог периода открива већи пад економских активности, недостатак одговарајућих информација, недоступност здравствених установа, већи губитак послова, вишу стопу смртности на глобалном плану у сеоским подручјима (Strath, 1919). Тај извештај такође објашњава да је друштвени и економски утицај епидемије, нарочито међу америчким Индијанцима, који су већином живели у сеоским подручјима, био „крајње снажан” и знатно већи него међу онима у градским подручјима. Стопа смртности била је 4 пута виша у сеоским подручјима него стопа забележена у већим градовима у земљи.

Исти случај био је и са аутохтоним староседеоцима, тј. Абориџинима у руралним заједницама Аустралије. Док је код осталих Аустралијанаца који живе у градским подручјима стопа смртности у просеку износила $0,4 \%$, насупрот томе, заједница Абориџина у оквиру сеоских подручја у Аустралији имала је стопу смртности изнад 50\% (Massey et al., 2009). Честа и интензивна изложеност вирусу, услед скученог животног простора и ограниченог приступа здравственој нези, допринела је вишој стопи заразе, као и повећаној смртности и смањењу економских активности у овим заједницама (Strath, 1919; Massey et al., 2009).

Пандемије новијег датума такође су потврдиле сличне трендове. На пример, свињски грип H1N109 из 2009. године имао је много разорније друштвено-економске утицаје на заједнице у сеоским него у градским подручјима (Groom et al., 2009; Massey et al., 2009; Parker et al., 2009; Andrulis et al., 2012). Истраживање броја смртних случајева у Аустралији током пандемије указује на то да су аутохтони становници Аустралије имали упадљиво већу смртност (Massey et al., 2009). Студија показује да је постојала приближно пет пута већа вероватноћа да ће особе из руралних заједница у односу на остале бити хоспитализоване због свињског грипа (Massey et al., 2009). Исти број људи такође је захтевао интензивну негу како би имао шансе да преживи пандемију. Због даљег пада присутности владе и друштвено-економских активности, недостатка информација о пандемији и недоступности аустралијских служби за социјалну помоћ и здравствене услуге, ове заједнице постале су осетљивије на озбиљне друштвено-економске изазове и све израженије здравствене ризике, што је довело до повишене стопе смртности у односу на заједнице у градским подручјима (Massey et al. 2009).

Вирус хумане имунодефицијенције (HIV) који је захватио Африку 70-их година 20. века, као и најновија епидемија еболе 2014. године, представљали су разорније изазове у сеоским него у градским подручјима (Booysen et al., 2002; Oni et al., 2002; Parker et al., 2009; World Bank Report, 2013; Richards et al., 2015), и поред тога што су ове болести прво откривене у градским подручјима. Као што је већ речено, сеоска домаћинства претрпела су озбиљније последице. Установе за дијагностиковање и лечење ових 
болести углавном се не налазе у сеоским подручјима у истом броју као у градским подручјима (Oni et al., 2002). Због тога је ово финансијски и временски ефикасно за људе у градским подручјима. У већини случајева, људи који живе у сеоским подручјима прелазе велику удаљеност да би дошли до здравствених установа. Ови изазови указују на потребу за побољшањем развоја инфраструктуре, како у здравственом, тако и у образовном систему у сеоским подручјима; то питање требало би хитно решити.

Емпиријски гледано, ни Јужна Африка није имуна на ове изазове (Booysen et al., 2002; Oni et al., 2002; Parker et. al., 2009; Alexander, 2010; Chikulo, 2016; Brinkerhoff et al., 2018), а истраживања о претходним пандемијама показују како су се сеоска домаћинства борила са разорним изазовима. Ова студија спроведена је у циљу испитивања изазова са којима су се домаћинства у сеоским подручјима суочила током изолације услед COVID-19. Ова студија помаже да се створи представа о томе кроз шта људи у сеоским подручјима пролазе током изолације. Налази студије пред вама односе се на општину из округа Вембе и могу се употребити за израду и обликовање мера политике које влада предузима како би одговорила на ширење вируса COVID-19. Студија указује влади на то да интересе људи у сеоским подручјима током пандемије не би требало да разматра тек накнадно. Она позива владу да размотри одговарајуће мере које могу да обезбеде одрживост сеоских домаћинстава током сличних глобалних криза у будућности.

\section{Метод рада}

Студија је усвојила метод студије случаја које омогућава сакупљање и анализу квалитативних података (Creswell, 2017). Ово је идеалан метод имајући у виду да даје простора за интеракцију и истраживање искустава испитаника о изолацији изазваној вирусом COVID-19. Због правила о ограниченом кретању и социјалној дистанци, директан контакт са испитаницима није био могућ. Стога су за обављање дубинских интервјуа један на један са испитаницима примењене технике електронског сакупљања података као што су телефон, Skype и WhatsApp. Међутим, пре сакупљања података примењена је техника смишљеног узорковања како би девет студената Универзитета у Венди били идентификовани као главни даваоци информација. Образложење је засновано на чињеници да ти студенти потичу из домаћинстава у сеоским подручјима у округу Вембе, у провинцији Лимпопо. Они су били у контакту са сличним домаћинствима у сеоским подручјима. Такође су говорили аутохтоне језике као што су Венда и Тсонга, а познавали су и технику електронског сакупљања података.

Студија се ослонила на полуструктуриране дубинске интервјуе са главама домаћинстава из 12 села у округу Вембе (видети Табелу 1 . Користећи одговарајућу технику узорковања, студенти су успели да са 82 испитаника разговарају о изазовима током ванредног стања. Међу испитаницима је било 57\% жена и 43\% мушкараца. Дубински интервјуи обављени су према принципу сатурације података.

Интервјуисани су само они испитаници који су прихватили етичку сагласност студије. Изјаве добијене од 82 испитаника сачуване су у Microsoft word документу и унете у софтвер Atlas.ti v8 ради квалитативне анализе. За анализу је коришћен отворени систем кодирања унутар софтвера. Ово је било корисно за категоризацију изјава испитаника по темама. 


\section{Област истраживања}

Област истраживања налази се у округу Вембе, у провинцији Лимпопо на северу Јужне Африке. Граничи се са Боцваном, Мозамбиком и Зимбабвеом. Округ се састоји од четири локалне општине: Колинс Чабане, Туламела, Макадо и Мусина. Дванаест села за ову студију одабрано је на основу руралности и удаљености од услужних центара. Баш као и сваки други округ у провинцији, Вембе је познат по свом превасходно руралном карактеру и по великој скали основних пољопривредних делатности. Ово, заједно са разним другим видовима пословања, доприноси великом уделу одрживог начина живота.

Округ има више од 1,1 милион становника и површину од 21.407 км$^{2}$ (Statistics South Africa, 2011). Ова област је углавном руралног карактера и недостају јој кључне основне службе (Chauke et al., 2013). Процењује се да има удео од 4,4\% у укупној пољопривредној производњи, 8,4\% у производњи суптропског воћа и 6,3\% у производњи цитруса (Vhembe District Municipality, 2018). Лимпопо је једна од провинција са највишим нивоом сиромаштва и незапослености у земљи, чему у знатној мери доприноси округ Вембе. Већина домаћинстава прехрањује се од продаје на тезгама поред пута, микро-предузећа и осталих видова основних послова.

\section{Резултати истраживања}

Као што се види на Слици 1 идентификовано је пет главних тема и неколико ставки. На првом месту је набавка основних потрепштина као што су намирнице, вода и медицинска помоћ. Извор прихода погођен смањењем трошкова и затварањем малих предузећа представља наредни изазов. Помињу се депресија и фрустрираност изазване страхом од заразе, супружничко злостављање, немогућност испуњавања кућних обавеза, досада изазвана ограниченим кретањем, као и породичне свађе. Препознати су и „приступ неопходним информацијама” који доводи до анксиозности, као и „крађа”.

\section{Основне потребе}

Током ванредног стања, приступ здравственим установама био је изазов за поједина сеоска пребивалишта. Иако је влада све облике здравствених система као што су болнице, клинике и локалне апотеке категоризовала као неопходне, омогућивши им да раде током ванредног стања, већина њих, нарочито оних у приватном власништву, није била ефикасна и са скепсом се постављала према потребама људи у сеоским подручјима. Разлог за то првенствено је био страх од вируса. Ово је постао озбиљан изазов за људе у сеоским домаћинствима јер су морали да пређу велику удаљеност како би дошли до здравствених установа:

„...Нисам моїао gа о овеgем суйруіу у болнииу; немам среgстиава за йривайни ӣревоз из села gо іраgа. Чак и каgа смо йокушали gа нам болнииа обезбеgи кола хийне йомоћи, нисмо ообили никакав оgі̄овор...” (P2)

Неоспорно је да је влада увела мере које олакшавају кретање основних служби као што је здравство. Ипак, те мере су у већини случајева биле онемогућене поступањем радника обезбеђења приликом примене закона. 
„...Раяници обезбеђеюа не чекају никакво објашюеюе; оgмах йуку, йа чак и оgвоgе у йрийвор све оне које заиекну без дозволе..." (Р7).

Многи су такође поменули фрустрираност због напорног процеса добијања дозволе за кретање из једне заједнице у другу од полицијских органа, политичких представника или традиционалних поглавара. Недостатак превоза довео је до дугачких редова испред болница, због чега неки људи нису успели ни да уђу. Болнице су биле претрпане јер су опслуживале многобројна села, а то је за резултат имало брзо ширење вируса.

„Плашимо се gа би отиаи, ако іа оgвеgемо у болнииу, моїао gа gобије вирус и gа умре. Зوравстивени раяници у нашој областии нишита не знају. Болнице су већином ирретириане; зяравстивени раяници чак не ирименују ситроіе мере ирреgостирожносиии йоком йандемије..." (Р27).

За време ванредног стања у трајању од 21 дана затворена је већина малих предузећа у селима. Радило је свега неколико самоуслуга у удаљеним и сеоским подручјима. Људи у удаљеним подручјима били су присиљени да прелазе велику удаљеност како би купили залихе намирница које ће им послужити неколико седмица. Јавни саобраћај био је ограничен на одређени временски период, па је кретање било ограничено између $6 \mathrm{~h}$ и $10 \mathrm{~h}$ ујутру, односно $4 \mathrm{~h}$ и $10 \mathrm{~h}$ поподне. Осим изазова у виду чекања превоза, и редови у тржним центрима представљали су озбиљну потешкоћу. Велика потражња заштитне опреме, на пример дезинфекционих средстава и маски, као и повећане цене прехрамбених производа, оставиле су сиромашнима једину опцију - да се одрекну неких основних намирница. Појединих намирница није било на залихама, као што је наведено у тексту испод.

„...Сеоске йрояавнице нису gобијале довољно залиха; йо изазива инфлацију, ойежавајући нам набавку основних ӣотиреититина збоі оірраничених среgстиава..." (Р12).

„Влаgа је тиребало да субвенционише основне намирнице, gа формира раяну іруӣу за контиролу цена како би сиречита инфлаиију основних намирница. Љуgи раgе шита им се

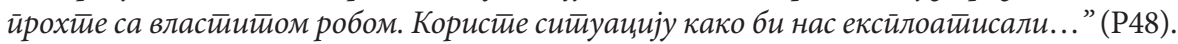

„Само смо чули за залихе личне зашииитине оирреме коју тьуди gобијају, очиілтеgно су они раниви на маріини...; нисмо нишита вияели.” „Чак и воgа за коју је влаgа обећала

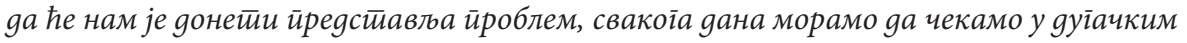
реgовима како бисмо добили воgу...” „... Влаgа тиражи оg нас gа иеремо руке водом иако је немамо довољно ни за йиће." (Р34).

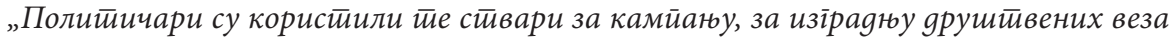

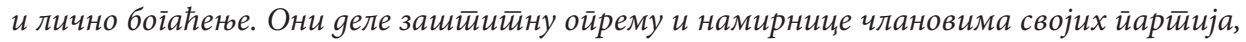
йријаиеельма и йородиии." (Р1).

\section{Извор прихода}

Као и у градским подручјима, сви облици економских активности морали су да буду обустављени и у сеоским подручјима. Само предузећима која пружају основне услуге било је дозвољено да раде током ванредног стања. Власници малих предузећа, нарочито продавци, престали су да раде у складу са правилима о изолацији. 
Ивара и сар., COVID-19 и gрушичвено-економски изазови...

Нажалост, нека од тих предузећа престала су са радом пре истека ванредног стања од 21 дана. Тако су уштеђевина, социјална помоћ и донације прехрамбених пакета били једини начин да се преживи. Ово је постао огроман изазов за све који су се издржавали само од донација прехрамбених пакета:

„Влаgа није тиребало gа укине изворе ӣрихоgа на које се сеоско сииановнишитво ослана йре неїо шито обезбеgи оgіоварајуће алитернаииивне мере йоgрике. Било је моіућћ

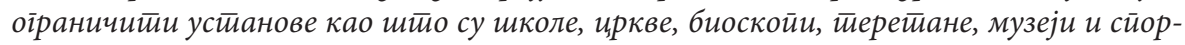
йски gоїађаји, али не и мала ирреgузећа која нам заgовољавају основне йойребе..." (Р11)

„Свако йреgузеће је неойходно юеі̄овом власнику, йа ми није јасно шита влаgа

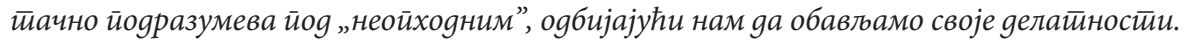

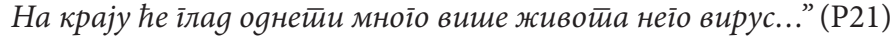

„Мала йреgузећа која обезбеђују храну на сииолу сеоскоі стиановнишиива зайво-

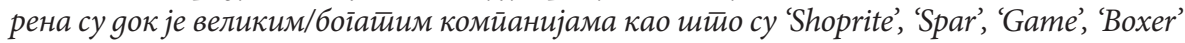

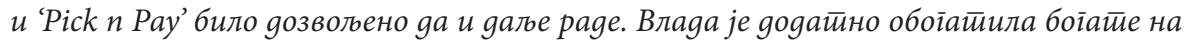

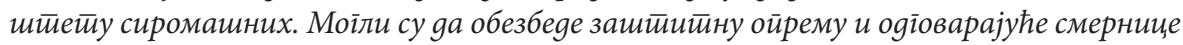
власнииима малих ӥреgузећа како би им иомоіли ga page и зараgе за животи...” (63)

\section{Борба са депресијом и фрустрацијом}

Ванредно стање је ограничило кретање, затворивши људе у куће. Досада постаје велики проблем људима који су сами, док је многима другима тешко да се изборе са понашањем људи око себе.

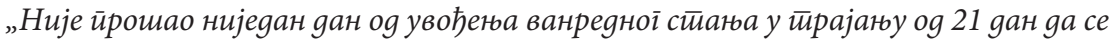

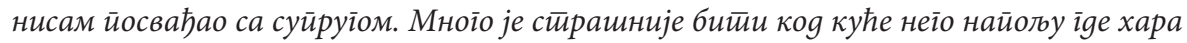
вирус. Да није ванредноі сйана, био бих на раяном местиу или бих се gружио са йријаиеелима како бих се уяатьо оg юе; искрено іоворећи, у клойци сам...” (Р7).

„Или само секс или храна...” „Суйруї ме свакоїа gана тичче. Зативорио ме је у кавез и раяи све шито йожели. Обично ми сусеgи йомоінн, али су саg йрестиали gа долазе збоі

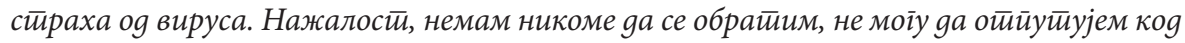

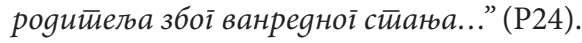

Страх од губитка прихода, од гладовања и могућег краја света проузрокованог пандемијом заокупља мисли чланова многих домаћинстава. Исто тако, постоји забринутост због супружничког насиља, као и притиска у вези са испуњавањем кућних обавеза као што су набавка хране и плаћање режија. Овај изазов је упадљиво променио структуру потрошње у домаћинствима јер многа од њих морају да штеде на ограниченим ресурсима попут хране, воде и струје како би преживели изолацију. Неки испитаници имали су проблема са плаћањем станарине. Многима је проблем представљао простор. Простор је постао скучен јер су се сви вратили кући због вируса COVID-19. Са некима су брачни партнери и деца:

„...Осећао сам се безнаяежно вияевии како се боримо да заяовољимо основне йой-

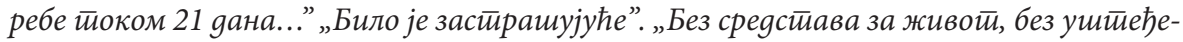

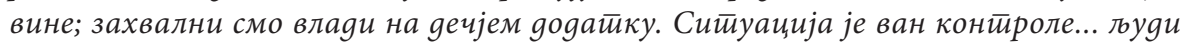
йāue ..." (Р31). 


\section{Приступ неопходним информацијама}

Сеоска домаћинства уверена су да свест о пандемији није била довољно развијена у њиховим крајевима. Бројне породице у сеоским подручјима боре се да би од владе добиле вести из прве руке и схватиле о каквом је вирусу реч, не рачунајући оне који могу да приуште телевизијске и радио апарате. Као резултат, многи се ослањају на суседе или пријатеље када су им потребне основне информације. Без обзира на извор, цени се све што их обавештава о узроку пандемије, мерама предострожности и леку за вирус. Нека домаћинства су изјавила следеће:

„... Tрудимо се gа сазнамо шита је зайраво COVID-19. Нико не уме gа нам йо боле објасни у овом селу. Све шито смо вияели били су раяници обезбеђень који ияу наоколо и иррисиљавају льуде gа остиану коg куће...” (Р16).

„Пре извесноі времена ирравили смо найитике оg лимуна и ђумбира. Јеgан сусеg нам је рекао gа је тио ефикасно средсииво у лечену вируса. То смо ииили уместио чаја ујуштру и увече све док нам је ћерка која живи у іраgу рекла gа оситанемо коg куће, gа је вирус ойасан и gа за неїа још нема лека. Усйаничили смо се...” „....Можgа би анїажоване заједнице и реаіованье на йандемију сманило тажне информације и ойклонило забринуйости са којом се суочавају они раниви...” (Р19).

Међу испитаницима је широко распрострањено уверење да су људима који живе у удаљеним и сеоским подручјима Јужне Африке и даље ускраћена људска права попут приступа информацијама о образовању, приступа ресурсима као што су интернет и струја, који су неопходни за образовање, и приступ самом образовању. Иако је школовање бесплатно, недостатак основне инфраструктуре у појединим областима многима ускраћује привилегије:

„...Нису сасвим јасни начини које је влаgа увела gа би унайреgила учете елекйронским йуием, нико са нама није разіоварао о йоме gа се оg ђака очекује gа имају онлајн насииаву. Нажалосии, моја gеи, ће бити у заосииаику са іраgивом; йореg рачунара који немамо gа бисмо ирреузели матиеријал за учетье, у овом селу је велики ироблем и йристичй иниетернетич...” (Р71).

$$
\text { Крађа }
$$

Док се од свих осим од радника са основним делатностима очекује да остану код куће, криминал расте током пандемије COVID-19. Затворене школе и продавнице су обијене и опљачкане. Поједина домаћинства такође су се нашла на мети провалника, што је повећало њихову трауму због вируса COVID-19.

„Локалне банgе ияу наоколо йоком овоі ӥериоgа и краgу оg тууди у селу. Пъачкају йуђе йосеgе. То је зайо шйо је ово време йовећало ниво безнађа."

Домаћинства која су доживела овакве инциденте очигледно су морала да се суоче са губитком ионако оскудних средстава, крајње неопходних током изолације. У већини случајева испитаници су окривили владу због увођења ванредног стања без одговарајућих безбедносних мера. 


\section{Дискусија}

Ова студија препознала је бројне изазове са којима се боре сеоска домаћинства у округу Вембе током ванредног стања у Јужној Африци због вируса COVID-19. Изазови су категоризовани у пет група. Оне обухватају задовољавање основних потреба као што су намирнице, вода и здравствене услуге; ограничен извор прихода услед смањивања трошкова и затварања малих предузећа; депресија и фрустрираност проистекле из страха од заразе вирусом, супружничко злостављање, немогућност испуњавања кућних обавеза и породичне свађе, као и досада изазвана ограниченим кретањем; немогућност приступа неопходним информацијама о вирусу; и крађа.

Ови изазови очигледно нису далеко од претходних истраживања у вези са сеоским домаћинствима на глобалном плану и у контексту Јужне Африке. То указује да је ова студија само допринела кристалисању и дефинисању изазова. Аргумент је у складу са истраживањима која су спровели Massey et al. (2009), Parker et al. (2009) и Светска банка (World Bank Report, 2020), где је утврђено да је приступ основним услугама био веома озбиљан изазов за људе који живе у сеоским подручјима, нарочито током глобалних здравствених криза. Као и у претходним студијама (Massey et al., 2009, Parker et al., 2009 \& World Bank, 2020), ови изазови (приступ здравственим установама, основне потребе и недостатак информација) наглашавају поновљене проблеме са којима се људи у сеоским подручјима у свим крајевима света суочавају у свакодневном животу. Овакво стање ствари постаје још упадљивије уочи обустављања друштвених и економских активности због избијања вируса COVID-19. Њихова озбиљност такође је погоршана зато што опстанак људи који живе у тим заједницама у потпуности зависи од друштвених и економских активности које су обустављене увођењем ванредног стања ради заустављања ширења вируса COVID-19.

Други значајан аспект налаза ове студије јесте потврда да су сеоска домаћинства у округу Вембе трпела и да им је влада ускратила приступ основним услугама (Emenike et al., 2017; Drummond \& Snowball, 2019; Fransman \& Yu, 2019). Налази ове студије, баш као и они у горе поменутим студијама, показују да је приступ путевима, водоснабдевању, струји и интернету и даље изазов за сеоска домаћинства. У овој ситуацији, људи попут студената који живе у сеоским подручјима највише трпе јер је доступност наведених ресурса од пресудног значаја за њихов академски ангажман. За разлику од људи у осталим деловима земље, они су у заостатку у програму електронског учења који влада подстиче. Уопштено узев, налази указују на постојање велике разлике у обезбеђивању основних услуга за сеоске и градске заједнице. Државе обично дају приоритет људима који живе у великим градовима на штету оних у сеоским заједницама. Градска подручја привлаче велики део државних инвестиција у инфраструктуру, док се мало пажње посвећује сеоским заједницама где су те услуге изузетно потребне (Vearey et al., 2010; Saleem \& Abideen, 2011; van der Hoeven et al., 2012; Brain et al., 2014; Walker \& Mathebula, 2019). Иако сеоска подручја значајно доприносе када је реч о сировинама, храни и радној снази које су неопходне за одржавање градских економија (van der Hoeven et al., 2012), она су и даље маргинализована када дође до распоређивања основних услуга. Пандемија COVID-19 указала је на потребу за напреднијим обезбеђивањем ових основних услуга, нарочито интернета и доступности осталих основних услуга у сеоским подручјима. 
Претходно је дискурс у извештају Emerging Voices (2005) приказао маргинализацију сеоских домаћинстава и изразио забринутост да уколико се не дефинише, прихвати и адекватно размотри стварни јаз између градских и сеоских подручја, неједнакости ће и даље постојати и пратити будуће нараштаје. Током две деценије од укидања апартхејда, сеоска подручја у земљи и даље се боре са непремостивим препрекама а на видику су незнатне или готово никакве промене за оне којима су оне најнеопходније (Moletsane, 2012; Mburu \& George, 2017; Drummond \& Snowball, 2019). Ово захтева брзе интервентне мере како би се решила неједнакост између села и града, сиромаштво, незапосленост, приступачност и доступност здравствене неге. Ефикасност свега што је до сада урађено у Јужној Африци у погледу решавања неједнакости између села и града и даље се доводи у питање с обзиром на то да се мало тога променило у Јужној Африци после 25 година од увођења демократије. Научници као што су Turpie et al. (2008), De Kadt \& Lieberman (2017), Ndebele и Lavhelani (2017), те Nkomo (2017) окрили су да народне масе често тај неуспех приписују високом степену корупције, некомпетентности и етничке подељености.

Са емпиријског становишта, већина сеоских домаћинстава опстаје захваљујући основној земљорадњи, микро-предузећима и ситним пословима (Hunter et al., 2014; Ubisi et al., 2017; Wilkinson, 2017). Од зараде једва могу да уштеде нешто за тешка времена. Њихов опстанак зависи од свакодневних економских и друштвених активности земље. С обзиром на то, потпуно обустављање њихових економских и друштвених активности значи и потпуно укидање извора њихове зараде, односно гладовање. Иако је влада увела социјалне мере као што је повећање социјалне помоћи за R500 и помоћ у износу од R350 за званично незапослена лица у земљи (South Africa Government, 2020), изјаве испитаника указују на то да је ово сувише мало да би се људима у сеоским домаћинствима омогућило испуњавање основних потреба. У појединим случајевима, студија такође показује да је људима у сеоским подручјима често немогуће да добију помоћ од владе која им је првобитно намењена. Ово, заједно са страхом од глади, изазива већу панику него сам вирус.

Проблем крађе односно пљачке у Јужној Африци као предмет дискусије у време кризе детаљно је документован у литератури (Misago, 2019; Ngcamu \& Mantzaris, 2019; Marumo et al., 2019). Током кризе, људи у земљама у развоју често показују снажну тенденцију проваљивања и пљачкања државних и приватних поседа, нарочито у градским подручјима. На пример, услед ксенофобске кризе 2018. године у појединим деловима области Квазулу-Натал и Гаутенг су нападнута поједина предузећа, а на мети су углавном била насеља у поседу црних афричких миграната (Mngadi \& Njoli, 2018; Ogunnoiki \& Adeyemi, 2019). Сличан инцидент догодио се 2019, када је чак било и људских жртава (Times Live, 2019; Maromo, 2019). Године 2020, у јеку пандемије COVID-19, Јужноафриканци су у великом броју изашли на улице да би обијали и пљачкали продавнице (Times Live, 2020; SABC News, 2020). Самим тим, крађа током садашње кризе у земљи, поготово у градским подручјима, није ништа ново. Међутим, када је реч о сеоским заједницама, стиче се утисак да постоји веома оскудна или никаква литература на ту тему. Ово би могло значити да постоји релативно мали број случајева ових проблема у односу на градска подручја или да нема довољно документације. Није јасно које је мере влада увела да би спречила овакве инциденте. 
Попут крађе, породично насиље, нарочито родно засновано, такође је горуће питање у земљи (Sexual Violence Research Initiative, 2020). Вероватно оба пола врше и доживљавају партнерско злостављање. Међутим, анкете спроведене у становништву показују забрињавајући пораст насиља над женама, при чему је насилник најчешће њихов интимни партнер (Dunkle et al., 2004; Machisa et al., 2011; Sexual Violence Research Initiative, 2020). На пример, више од 56\% Јужноафриканки убијених током 2009. биле су жртве насиља које су починили њихови интимни партнери (Jewkes et al., 2009). Чак 40\% од укупног броја жена у земљи доживело је сексуално односно физичко насиље од интимних партнера (Jewkes et al., 2011; Jewkes, 2012), а више од $50 \%$ жена претрпело је емоционално или економско злостављање од стране њихових партнера (Jewkes, 2012; Sexual Violence Research Initiative, 2020). Да би се ублажио овај пораст, изгласана је наредба о заштити, а организације цивилног друштва и невладине организације (НВО) удружиле су снаге и саставиле Национални стратешки план, као и програме на којима се заснивају кампање против породичног тј. родно заснованог насиља.

У низу тих организација, FAMSA, Legal Aid South Africa, People Opposing Women Abuse (POWA) су функционална тела основана у циљу ограничавања пораста родно заснованог насиља. Летимичан поглед на ове организације показује да домен њиховог рада не покрива довољно сеоска подручја јер многим сеоским домаћинствима и даље недостају основне смернице о корацима које треба пратити у случају злостављања (Usdin et al., 2005; Dunkle et al., 2007; Lince-Deroche et al., 2018; Shai, 2018). Њима је још теже зато што не схватају своја права, којој приватној или државној институцији да се обрате или како да координишу своје поступке да би избегли дати сценарио с обзиром на то да живе у условима где је упадљиво одсуство владе. Ово би могло да доведе до снажног осећања несигурности и рањивости које се интернализује и преноси и на друге области њиховог живота.

Недостатак одговарајућих представника такође објашњава разлоге због којих се сеоска домаћинства боре за приступ основним информацијама (образовању) о пандемији. Ово често проузрокује анксиозност и депресију. Током кризе, сеоска домаћинства се углавном ослањају на свог представника који им улива наду. Изјаве испитаника показују да је влада уложила мали или никакав напор у разматрање овог питања. Основне информације као саставни део сваког разматрања и даље су доступне малом броју људи који могу себи да приуште приступ медијима. Изузев оних који имају приступ телевизору, радио апарату и паметном телефону, остали очигледно и даље нису свесни шта се дешава у осталим заједницама у земљи. То потврђује став који имају Balfour и De Lange (2012) када тврде да и поред тога што је образовање кључно за развој свести о окружењу, решавање друштвених изазова и неопходно за трансформацију, оно је и даље недовољно истражена димензија сеоског живота. Наводно, страх од даљег ширења вируса могуће је спречио политичке представнике и традиционалне поглаваре да предузму одређене мере. Дељење прехрамбених пакета током ванредног стања успешно је протекло чак и у сеоским подручјима (Asma, 2020; Mbuza, 2020; Pule, 2020); помоћу сличне технике могле би се поделити и неке информације. Током кризе битно је ставити сеоска домаћинства на друштвени ниво дешавања. 


\section{Закључак}

Одговор на пандемију подстакнут само медицинским или економским подацима очигледно није адекватан. Одговор на здравствене ризике попут ових треба да буде обликован према специфичним потребама у различитим демографијама земље. Стално повећавање ресурса за надзирање и праћење је од пресудног значаја, баш као и успешно управљање широким и нагло повећаним токовима података о ширењу пандемије. Ипак, подједнако важно је и разумевање друштвено-економских проблема са којима се суочавају људи у сеоским подручјима, где је помоћ најпотребнија, као и разумевање која је најделотворнија врста помоћи. Овакав начин разумевања може се постићи само помоћу поузданих друштвених података и инфраструктуре управљања која би реаговала и одговорила на потенцијалне кризе како у сеоским, тако и у градским подручјима. Ова истраживачка студија открива да је „задовољавање основних потреба" као што су намирнице, вода и здравствене услуге само један од изазова са којима се суочавају домаћинства у сеоским подручјима. „Извор прихода” за живот као резултат смањивања трошкова и затварања малих предузећа представља додатни изазов. Такође се помињу „депресија и фрустрираност” изазване страхом од вируса, супружничко насиље, немогућност испуњавања кућних обавеза, досада услед ограниченог кретања, као и породичне свађе. Међу изазовима су и „приступ неопходним информацијама” о вирусу, што доводи до анксиозности, као и „крађа”.

\section{Препоруке}

Пандемија COVID-19 указала је на потребу да влада унапреди развој инфраструктуре у сеоским подручјима. Основне погодности као што је покривеност интернетом, водовод, струја и асфалтирани путеви су неопходне и треба их обезбедити и у сеоским подручјима. Очекује се да ће развој инфраструктуре подстаћи оснивање услужних центара у близини, омогућавајући на тај начин лак приступ основним услугама. Информације су од пресудног значаја. Влада и традиционални поглавари треба да повећају укљученост сеоских домаћинстава у доношење одлука које се односе на њих. Корупција међу политичким представницима у земљи је и даље горуће питање које треба решити да би се обезбедила доступност основних услуга и у сеоским подручјима. Треба нагласити да је велики број налаза остао генерализован због одсуства квантитативних мера. Стога би будуће студије требало да искористе мере за испитивање препознатих изазова у ширем домену ради гаранције квалитета. 


\section{REFERENCES / ЛИТЕРATУРA}

Alexander, P. (2010). Rebellion of the poor: South Africa's service delivery protests-a preliminary analysis. Review of African political economy, 37 (123), 25-40. https://doi. org/10.1080/03056241003637870

Allen, A. (2010). Neither rural nor urban: service delivery options that work for the peri-urban poor. In M. Kurian, P. McCarney (Eds.) Peri-urban water and sanitation services (pp. 27-61). Dordrecht: Eastern Cape: Springer.

Andrulis, D. P., Siddiqui, N. J., Purtle, J. and Cooper, M. R. (2012). H1N1 Influenza Pandemic and Racially and Ethnically Diverse Communities in the United States. Available at:https://www.texashealthinstitute.org/uploads/1/3/5/3/13535548/thi_pandemic_influenza_equity_report_2012.pdf(Accessed 20 May 2020).

Asma, A. D. (2020). Covid-19: Food relief distribution for needy families in Gauteng. Available at: https://www.timeslive.co.za/news/south-africa/2020-04-01-covid-19-food-relief-distribution-for-needy-families-in-gauteng (Accessed 12 May 2020).

Bain, R. E., Wright, J. A., Christenson, E. and Bartram, J. K. (2014). Rural: urban inequalities in post 2015 targets and indicators for drinking-water. Science of the Total Environment, 490, pp. 509-513.https://doi.org/10.1016/j.scitotenv.2014.05.007

Balfour, R. J., De Lange, N., Khau, M. (2012). Rural education and rural realities: The politics and possibilities of rural research in Southern Africa. Perspectives in Education, 30 (1), pp. i-ix.

Bogoch, I. I., Watts, A., Thomas-Bachli, A., Huber, C., Kraemer, M. U. and Khan, K. (2020). Potential for global spread of a novel coronavirus from China. Journal of travel medicine, 27 (2), taaa011 doi: 10.1093/jtm/taaa011

Booysen, F. L. R., Bachmann, M., Matebesi, Z. and Meyer, J. (2002). The socio-economic impact of HIV/AIDS on households in South Africa: Pilot study in Welkom and Qwaqwa, Free State Province. Bloemfontein: University of the Free State.

Brinkerhoff, D. W., Wetterberg, A. and Wibbels, E. (2018). Distance, services, and citizen perceptions of the state in rural Africa. Governance, 31(1),103-124. https://doi. org/10.1111/gove.12271

Chan, J. F. W., Yuan, S., Kok, K. H., To, K. K. W., Chu, H., Yang, J., Xing, F., Liu, J., Yip, C. C. Y., Poon, R. W. S. and Tsoi, H. W. (2020). A familial cluster of pneumonia associated with the 2019 novel coronavirus indicating person-to-person transmission: a study of a family cluster. The Lancet, 395 (10223), 514-523. https://doi.org/10.1016/ S0140-6736(20)30154-9

Chauke, P. K., Nekhavhambe, T. D., and Pfumayaramba, T. K. (2013). An assessment of support provided to smallholder farmers: A case study of the Vhembe District, South Africa. African Journal of Agricultural Research, Vol. 8 (12),1077-1085. doi: 10.5897/ AJAR12.576.

Chikulo, B. C. (2016). “The Smoke That Calls”: A Review of Service Delivery Protests in South Africa 2005-2014. Journal of Human Ecology, 55(1-2), 51-60. https://doi.org/ 10.1080/09709274.2016.11907009

Creswell, J. W. and Creswell, J. D. (2017). Research design: Qualitative, quantitative, and mixed methods approaches. New York: SAGE Publications. 
De Kadt, D. and Lieberman, E. S. (2017). Nuanced accountability: Voter responses to service delivery in southern Africa. British Journal of Political Science, 50 (1) 185-215. https://doi.org/10.1017/S0007123417000345

Dlomo, L. (2020). Third coronavirus case in SA confirmed - and it's the wife of the first man to be diagnosed. Available at: https://www.sowetanlive.co.za/news/south-africa/2020-03-08-third-coronavirus-case-in-sa-confirmed-and-its-the-wife-of-thefirst-man-to-be-diagnosed/?fbclid=IwAR0yckA5f7MA6_UjShFnJZq11kL08jV. ENPtG_UeT0-dSi3k6ttWHC3EK6Xk(Accessed 18 May 2020).

Drummond, F. and Snowball, J. (2019). Cultural clusters as a local economic development strategy in rural small-town areas: Sarah Baartman district in South Africa. Bulletin of Geography. Socio-economic Series, 43 (43), 107-119. https://doi.org/10.2478/bog-2019-0007

Dunkle, K. L., Jewkes, R., Nduna, M., Jama, N., Levin, J., Sikweyiya, Y. and Koss, M. P. (2007). Transactional sex with casual and main partners among young South African men in the rural Eastern Cape: prevalence, predictors, and associations with gender-based violence. Social science \& medicine, 65 (6), 1235-1248.https://doi. org/10.1016/j.socscimed.2007.04.029

Dunkle, K. L., Jewkes, R. K., Brown, H. C., Yoshihama, M., Gray, G.E., McIntyre, J. A. and Harlow, S. D. (2004). Prevalence and patterns of gender-based violence and revictimization among women attending antenatal clinics in Soweto, South Africa. American journal of epidemiology, 160 (3), 230-239. doi: 10.1093/aje/kwh194

Emenike, C. P., Tenebe, I. T., Omole, D. O., Ngene, B. U., Oniemayin, B. I., Maxwell, O. and Onoka, B. I. (2017). Accessing safe drinking water in sub-Saharan Africa: Issues and challenges in South-West Nigeria. Sustainable cities and society, 30, 263-272. https:// doi.org/10.1016/j.scs.2017.01.005

Fransman, T. and Yu, D. (2019). Multidimensional poverty in South Africa in 200116. Development Southern Africa, 36 (1), 50-79. https://doi.org/10.1080/0376835X. 2018.1469971

Groom, A. V., Jim, C., LaRoque, M., Mason, C., McLaughlin, J., Neel, L., Powell, T., Weiser, T. and Bryan, R. T. (2009). Pandemic influenza preparedness and vulnerable populations in tribal communities. American Journal of Public Health, 99(S2), S271-S278. doi: 10.2105/AJPH.2008.157453

Hunter, L. M., Nawrotzki, R., Leyk, S., Maclaurin, G. J., Twine, W., Collinson, M. and Erasmus, B. (2014). Rural outmigration, natural capital, and livelihoods in South Africa. Population, space and place, 20 (5), 402-420.https://doi.org/10.1002/psp.1776

iReport South Africa, 2020. South Africa 21-day lock-down rules you need to follow or face jail time. Available at:https://ireportsouthafrica.co.za/2020/03/25/south-africa-21day-lock-down-rules-you-need-to-follow-or-face-jail-time/ (Accessed 5 May 2020).

Jewkes, R., Sikweyiya, Y., Morrell, R. and Dunkle, K. (2009). Understanding men's health and use of violence: interface of rape and HIV in South Africa. Cell, 82(442), p. 3655.

Jewkes, R., Sikweyiya, Y., Morrell, R. and Dunkle, K. (2011). Gender inequitable masculinity and sexual entitlement in rape perpetration South Africa: findings of a crosssectional study. PloS One, 6(12).https://doi.org/10.1371/journal.pone.0029590

Kaplan J. (2020). A third of the global population is on coronavirus lock-down - here's our constantly updated list of countries and restrictions Business Insider [Online] Available at: https://www.businessinsider.co.za/countries-on-lock-down-coronavirus-italy-20203? $\mathrm{r}=\mathrm{US} \& \mathrm{IR}=\mathrm{T}$ (Accessed 25 May 2020). 
Lam, H. Y., de Vera, R., Rivera, A. S., Sy, T. R., Cheng, K. J. G., Farrales, D. B., Lopez, J. C. F. and Miguel, R. T. D. (2018). Describing the health Service Delivery Network of an urban poor area and a rural poor area. Acta Medica Philippina, 52(5), 438-446.

Lince-Deroche, N., Shochet, T., Sibeko, J., Mdlopane, L., Pato, S., Makhubele, Q.S. and Bessenaar, T. (2018). 'You can talk about condoms [with younger men] while older men... beat you for that': Young women's perceptions of gender-based violence within intergenerational relationships in South Africa. South African Medical Journal, 108(8), 682686. doi:10.7196/SAMJ.2018.v108i8.12794

Machisa, M., Jewkes, R., Lowe-Morna, C. and Rama, K. (2011). The war at home. Johannesburg: Gender Links (1), pp. 1-19.

Marumo, P. O., Chakale, M. and Mothelesi, A. (2019). Xenophobia attack and development: a discourse in South Africa. African Renaissance, 16 (Special Issue 1 March 2019), pp. 185-198 doi : 10.31920/2516-5305/2019/s1n1a9

Massey, P., Pearce, G., Taylor, K. A., Orcher, L., Saggers, S. and Durrheim, D. (2009). Reducing the risk of pandemic influenza in Aboriginal communities. International Electronic Journal of Rural and Remote Health Research, Education, Practice and Policy, 9 (1), 1-7.

Mburu, G. and George, G. (2017). Determining the efficacy of national strategies aimed at addressing the challenges facing health personnel working in rural areas in KwaZulu-Natal, South Africa. African journal of primary health care \& family medicine, 9 (1), 1-8 http://dx.doi.org/10.4102/phcfm.v9i1.1355

Misago, J. P. (2019). Political mobilisation as the trigger of xenophobic violence in post-apartheid South Africa. International Journal of Conflict and Violence (IJCV), 13, a646-a646. DOI: https://doi.org/10.4119/ijcv-3118

Mnuza, N. (2020). SASSA gives food parcels to recipients whose grants lapsed due to Covid-19 lock-down. Available at:https://www.timeslive.co.za/news/south-africa/2020-04-07sassa-gives-food-parcels-to-recipients-whose-grants-lapsed-due-to-covid-19-lockdown/(Accessed 12 May 2020).

Moletsane, R. (2012). Repositioning educational research on rurality and rural education in South Africa: Beyond deficit paradigms. Perspectives in Education, 30 (1), 1-8.

Ndebele, C. and Lavhelani, P. N. (2017). Local government and quality service delivery: an evaluation of municipal service delivery in a local municipality in Limpopo Province. Journal of Public Administration, 52(2), 340-356.

Ngcamu, B. S. and Mantzaris, E. (2019). Xenophobic violence and criminality in the KwaZulu-Natal townships. TD: The Journal for Transdisciplinary Research in Southern Africa, 15(1), 1-8.

Nkomo, S. (2017). Public Service Delivery in South Africa: Councillors and Citizens Critical Links in Overcoming Persistent Inequities. Afrobarometer Policy Paper 42, 1-17.

Ogunnoiki, A. O. and Adeyemi, A. A. (2019). The Impact of Xenophobic Attacks on Nigeria-South Africa Relations. African Journal of Social Sciences and Humanities Research (AJSSHR), 2(2), 1-18.

Oni, S. A., Obi, C. L., Okorie, A., Thabede, D. and Jordan, A. (2002). The economic impact of HIV/AIDS on rural households in Limpopo Province. South African Journal of Economics, 70 (7), 551-562.https://doi.org/10.1111/j.1813-6982.2002.tb01189.x 
Parker, D. C., Jacobsen, K. H. and Komwa, M. K. (2009). A qualitative study of the impact of HIV/AIDS on agricultural households in South-eastern Uganda. International Journal of Environmental Research and Public Health, 6 (8), pp. 2113-2138. doi: 10.3390/ ijerph6082113

Phakathi, M. (2019). The role of music in combating xenophobia in South Africa. African Renaissance, 16 (3), 123-145. doi : 10.31920/2516-5305/2019/v16n3a7

Pule, A., 2020. Food parcels a lifeline for the needy. Available at: https://www.vukuzenzele. gov.za/food-parcels-lifeline-needy (Accessed 12 ${ }^{\text {th }}$ May 2020).

Richards, P., Amara, J., Ferme, M. C., Kamara, P., Mokuwa, E., Sheriff, A. I., Suluku, R. and Voors, M., 2015. Social pathways for Ebola virus disease in rural Sierra Leone, and some implications for containment. PLoS neglected tropical diseases, 9 (4). https://doi. org/10.1371/journal.pntd.0003567

Rothe, C., Schunk, M., Sothmann, P., Bretzel, G., Froeschl, G., Wallrauch, C., Zimmer, T., Thiel, V., Janke, C., Guggemos, W. and Seilmaier, M. (2020). Transmission of 2019$\mathrm{nCoV}$ infection from an asymptomatic contact in Germany. New England Journal of Medicine, 382(10), 970-971. doi: 10.1056/NEJMc2001468

SABC News 2020. Three people arrest after looting shops in the Cape Flats. Available at: https://www.sabcnews.com/sabcnews/three-people-arrest-after-looting-shops-in-thecape-flats/(Accessed 13 May 2020).

Saleem, S. and Abideen, Z. (2011). Examining success factors: Entrepreneurial approaches in mountainous regions of Pakistan. European Journal of Business and Management, 3 (4), 56-67.

Sexual Violence Research Initiative 2020. Gender-based violence in South Africa. Available at:https://www.saferspaces.org.za/understand/entry/gender-based-violence-insouth-africa (Accessed 11 May 2020).

Shai, P. N. (2018). Constructions of femininity in the context of sexual relationships among women living in the rural Eastern Cape province, South Africa (Doctoral dissertation, University of the Witwatersrand).

South Africa Government, 2020. President Cyril Ramaphosa: Measures to combat Coronavirus COVID-19 epidemic. Available at: https://www.gov.za/speeches/statement-president-cyril-ramaphosa-measures-combat-covid-19-epidemic-15-mar-2020-0000 (Accessed 17 March 2020).

South Africa Government (2020). Social relief of distress. https://www.gov.za/services/ social-benefits/social-relief-distress (Accessed 11 May 2020).

Statistics South Africa (Stats, S. A), 2011. Statistics South Africa. Formal census. Available at:http://www.treasury.gov.za/documents/national\%20budget/2002/ene/vote_13.pdf (Accessed 16 May 2020).

Strath, R. (1919). Influenza among American Indians. Public Health Rep, 34, pp. 1008-1009.

Times Live, 2020. COVID-19 WRAP | 2,415 cases in SA, looting at food shops and Ramaphosa requests time over booze ban. Available at: https://www.timeslive.co.za/news/ south-africa/2020-04-14-covid-19-live-updates-stupid-lock-down-laws-are-turningus-all-into-criminals/(Accessed 10 May 2020). 
Times Live. (2020). SA reeling after looting and attacks on foreigners in Joburg. Available at:https://www.timeslive.co.za/news/south-africa/2019-09-03-sa-reeling-after-looting-and-attacks-on-foreigners-in-joburg/(Accessed 5 April 2020).

Turpie, J. K., Marais, C. and Blignaut, J. N. (2008). The working for water programme: Evolution of a payments for ecosystem services mechanism that addresses both poverty and ecosystem service delivery in South Africa. Ecological economics, 65(4), 788-798. https://doi.org/10.1016/j.ecolecon.2007.12.024

Ubisi, N. R., Mafongoya, P. L., Kolanisi, U. and Jiri, O. (2017). Smallholder farmer's perceived effects of climate change on crop production and household livelihoods in rural Limpopo province, South Africa. Change and Adaptation in Socio-Ecological Systems, 3(1), 27-38. https://doi.org/10.1515/cass-2017-0003

Usdin, S., Scheepers, E., Goldstein, S. and Japhet, G. (2005). Achieving social change on gender-based violence: a report on the impact evaluation of Soul City's fourth series. Social science \& medicine, 61(11), 2434-2445. doi: 10.1016/j.socscimed.2005.04.035

Van der Hoeven, M., Kruger, A. and Greeff, M. (2012). Differences in health care seeking behaviour between rural and urban communities in South Africa. International journal for equity in health, 11(1), 31 doi: 10.1186/1475-9276-11-31

Vearey, J., Palmary, I., Thomas, L., Nunez, L. and Drimie, S. (2010). Urban health in Johannesburg: the importance of place in understanding intra-urban inequalities in a context of migration and HIV. Health place, 16 (4), 694-702. doi: 10.1016/j.healthplace.2010.02.007

Vhembe District Municipality (2018). Vhembe District Municipality - Overview. Available at https://municipalities.co.za/overview/129/vhembe-district-municipality (Accessed 11 March 2020).

Walker, M. and Mathebula, M. (2019). Low-income rural youth migrating to urban universities in South Africa: opportunities and inequalities. Compare: A Journal of Comparative and International Education, 1-17. Available at:https://www.tandfonline.com, doi/pdf/10.1080/03057925.2019.1587705?needAccess=true (Accessed 20 May, 2020).

Wax, R. S. and Christian, M. D. (2020). Practical recommendations for critical care and anesthesiology teams caring for novel coronavirus (2019-nCoV) patients. Canadian Journal of Anesthesia/Journal Canadien d'anesthésie, 67, 568-576. https://doi. org/10.1007/s12630-020-01591-x

WHO (2020c). Coronavirus disease 2019 (COVID-19) Situation Report - 87. Available at: https://www.who.int/docs/default-source/coronaviruse/situation-reports/20200326-sitrep-87-covid-19.pdf?sfvrsn=9e5b8b48_2(Accessed 19 May 2020).

WHO, (2020d). Coronavirus disease 2019 (COVID-19) Situation Report - 66. Available at: https://www.who.int/docs/default-source/coronaviruse/situation-reports/20200326-sitrep-66-covid-19.pdf?sfvrsn=9e5b8b48_2 (Accessed 19 May 2020).

Wilkinson, A., Pettifor, A., Rosenberg, M., Halpern, C. T., Thirumurthy, H., Collinson, M. A. and Kahn, K. (2017). The employment environment for youth in rural South Africa: A mixed-methods study. Development Southern Africa, 34 (1), 17-32.https:// doi.org/10.1080/0376835X.2016.1259986

World Bank Report (2013). Sierra Leone Growth Pole Diagnostic: The Growth Poles Program. Washington, DC: World Bank. 
World Bank (2020). The Economy in the Time of Covid-19. LAC Semiannual Report; April 2020. Washington, DC: World Bank.

World Health Organization (2020a). Coronavirus. Available at https://www.who.int/ health-topics/coronavirus\#tab=tab_1 (Accessed 15 April 2020).

World Health Organization (2020b). Novel coronavirus ( $\mathrm{nCoV} 2019$ ) situation as of 07 February 2020, 10:00 (CET). Available at:http://who.maps.arcgis.com/apps/opsdashboard/index.html\#/c88e37cfc43b4ed3baf977d77e4a0667(Accessed 8 May 2020).

Yusuf, B. (2018). The Politics of Pro-poor Service Delivery: Insights from Nigeria's Conditional Grant Scheme to Local Government Areas (Doctoral dissertation, University of Manchester).

Zhao, S., Lin, Q., Ran, J., Musa, S. S., Yang, G., Wang, W., Lou, Y., Gao, D., Yang, L., He, D. and Wang, M. H. (2020). Preliminary estimation of the basic reproduction number of novel coronavirus (2019-nCoV) in China, from 2019 to 2020: A data-driven analysis in the early phase of the outbreak. International journal of infectious diseases, 92, 214-217 https://doi.org/10.1016/j.ijid.2020.01.050 


\section{ПРИЛОГ/APPENDIX}

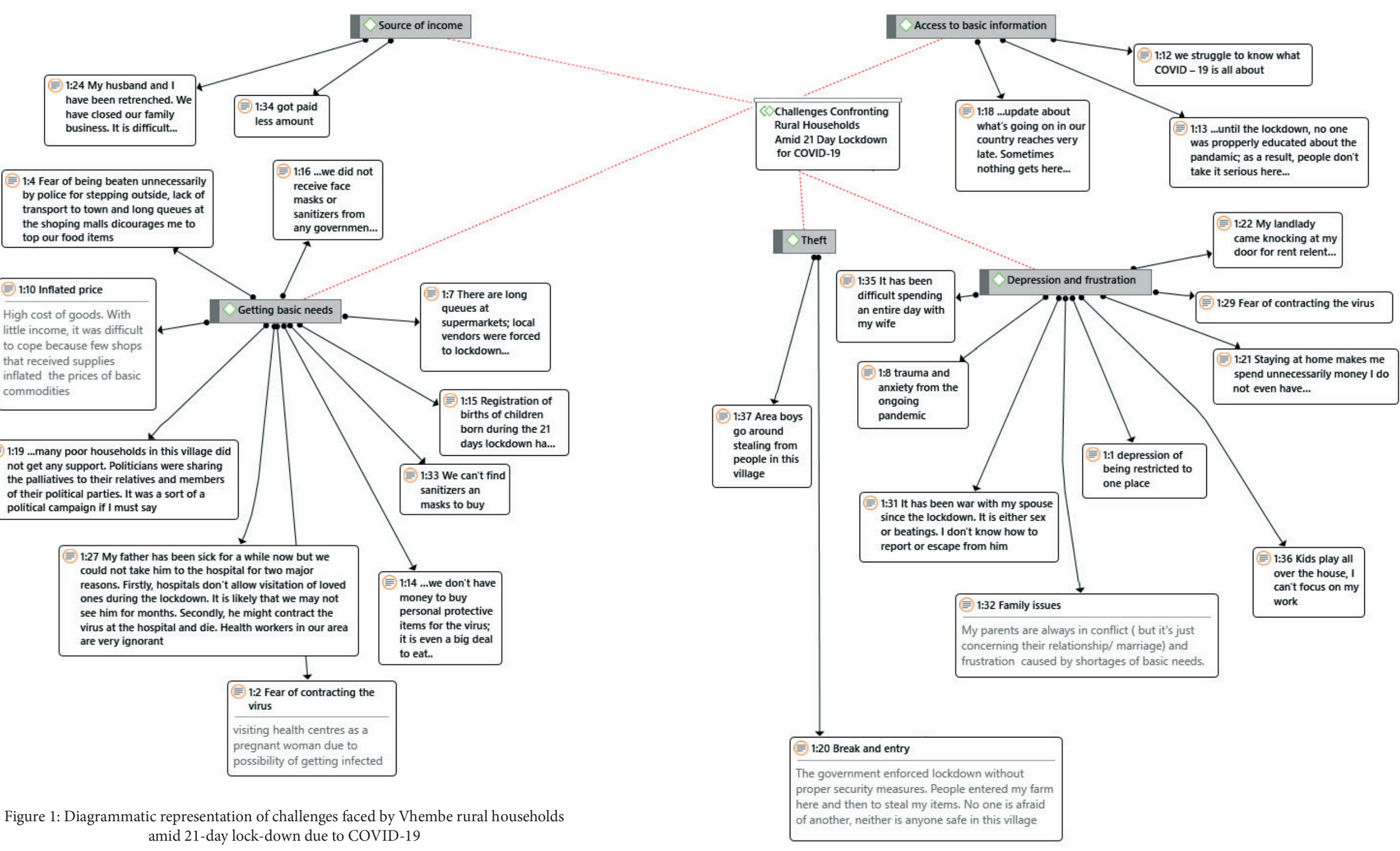



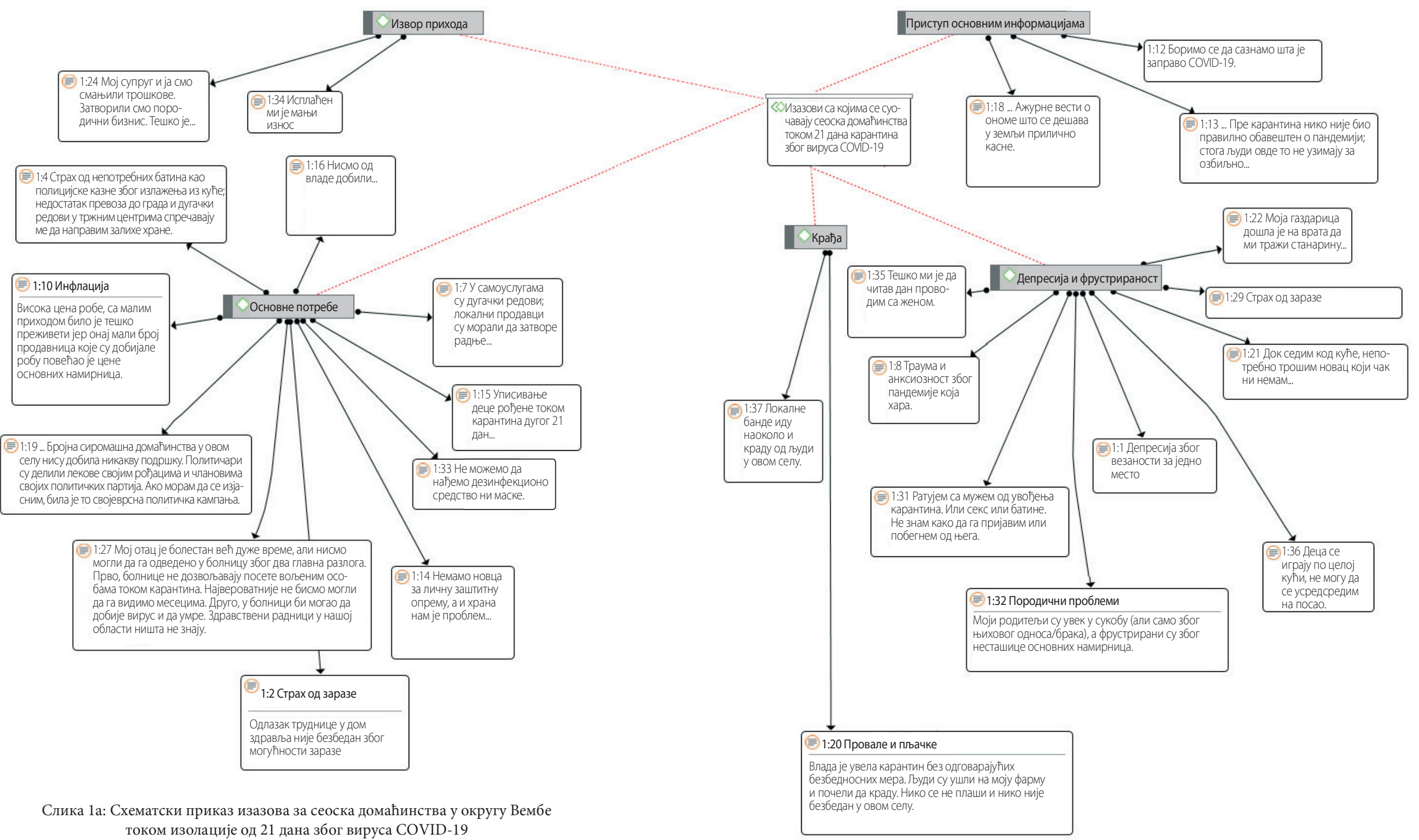
током изолације од 21 дана због вируса COVID-19 
Ивара и сар., COVID-19 и gрушиивено-економски изазови...

Table 1: Sample distribution of the study / Табела 1: Распоређеност узорка у студији

\begin{tabular}{|l|l|l|l|l|l|}
\hline \multirow{2}{*}{$\begin{array}{l}\text { Local Municipality/ } \\
\text { Локална општина }\end{array}$} & \multirow{2}{*}{ Village/Село } & \multicolumn{3}{|c|}{ Sample Distribution/Pacпоређеност узорка } \\
\cline { 3 - 7 } & & Frequency/ & $\begin{array}{l}\text { Percent/ } \\
\text { Проценат }\end{array}$ & $\begin{array}{l}\text { Female/ } \\
\text { Жене }\end{array}$ & $\begin{array}{l}\text { Male/ } \\
\text { Мушкарци }\end{array}$ \\
\hline Colins Chabane & Bungeni & 8 & & & \\
\hline & Nkensani & 7 & $27 \%$ & $15 \%$ & $12 \%$ \\
\hline & Muchipisi & 7 & & & \\
\hline Makhado & Mulima & 6 & & & \\
\hline & Muila & 8 & $23 \%$ & $13 \%$ & $10 \%$ \\
\hline & Sinthumule & 5 & & & \\
\hline Musina & Mutele & 7 & & & \\
\hline & Tshikundamalema & 7 & $24 \%$ & $15 \%$ & $9 \%$ \\
\hline Thulamela & Tshitanzhe & 6 & & & \\
\hline & Ha-Lambani & 7 & & & \\
\hline & Maraxwe & 8 & $26 \%$ & $14 \%$ & $12 \%$ \\
\hline Total/Укупно & Masisi & 6 & & & \\
\hline
\end{tabular}

Source: Authors/Извор: Аутори 